\title{
Classic and Variants APLs, as Viewed from a Therapy Response
}

\author{
Marie-Claude Geoffroy ${ }^{1,2,3}$ and Hugues de The ${ }^{1,2,3,4,5, *(1)}$ \\ 1 Institut National de la Santé et de la Recherche Médicale (INSERM) U944, Equipe Labellisée par la Ligue \\ Nationale contre le Cancer, 75010 Paris, France; marie-claude.geoffroy@inserm.fr \\ 2 Centre National de la Recherche Scientifique Unité Mixte de Recherche 7212, \\ Institut Universitaire d'Hématologie (IUH), 75010 Paris, France \\ 3 Institut de Recherche Saint-Louis, Université de Paris, 75010 Paris, France \\ 4 Assistance Publique-Hôpitaux de Paris, Service de Biochimie, Hôpital St-Louis, 75010 Paris, France \\ 5 Collège de France, PSL Research University, INSERM U1050, CNRS UMR 7241, 75005 Paris, France \\ * Correspondence: hugues.dethe@inserm.fr
}

Received: 24 March 2020; Accepted: 9 April 2020; Published: 14 April 2020

\begin{abstract}
Most acute promyelocytic leukemia (APL) are caused by PML-RARA, a translocation-driven fusion oncoprotein discovered three decades ago. Over the years, several other types of rare X-RARA fusions have been described, while recently, oncogenic fusion proteins involving other retinoic acid receptors (RARB or RARG) have been associated to very rare cases of acute promyelocytic leukemia. PML-RARA driven pathogenesis and the molecular basis for therapy response have been the focus of many studies, which have now converged into an integrated physio-pathological model. The latter is well supported by clinical and molecular studies on patients, making APL one of the rare hematological disorder cured by targeted therapies. Here we review recent data on APL-like diseases not driven by the PML-RARA fusion and discuss these in view of current understanding of "classic" APL pathogenesis and therapy response.
\end{abstract}

Keywords: leukemia; retinoic acid signaling; ATRA; ATO; PML; targeted therapy

\section{Introduction}

Acute promyelocytic leukemia (APL) accounts for 10-15\% of all acute myeloid leukemias (AML) with an annual incidence estimated at $0.0001 \%$ in Europe [1]. APL is a unique subtype of AML in which immature promyelocytes abnormally proliferate into the bone marrow. Classic APL is driven by a specific chromosomal translocation leading to the formation of PML-RARA, an oncogenic fusion protein found in over $98 \%$ of APL patients [2-5]. The resulting chimeric PML-RARA protein (Figure 1) promotes a clonal proliferation of myeloid precursors with a reduced differentiation capacity and acquisition of self-renewal. Pathogenesis of these "classic" APLs has been extensively reviewed elsewhere [6-8] and will only be sketched here. The World Health Organization (WHO) has revised the classification of AMLs, making APL with $\mathrm{t}(15 ; 17)$ (q24.1; q21.2), as a specific entity, but without taking in account the novel PML-independent RARs fusions [9]. Indeed, some other translocations driving the formation of fusion proteins have been described in very rare forms of leukemia with features of APL. While the genetics of these novel variant APL-like syndromes is now quite well delineated, their pathogenesis remains puzzling and treatment outcomes generally poor. Here, we review and put in perspective this recent literature on current understanding of genetic, pathogenesis and therapy response for these non "classic" APLs, stressing the role of global deregulated retinoic acid signaling in their pathogenesis. 


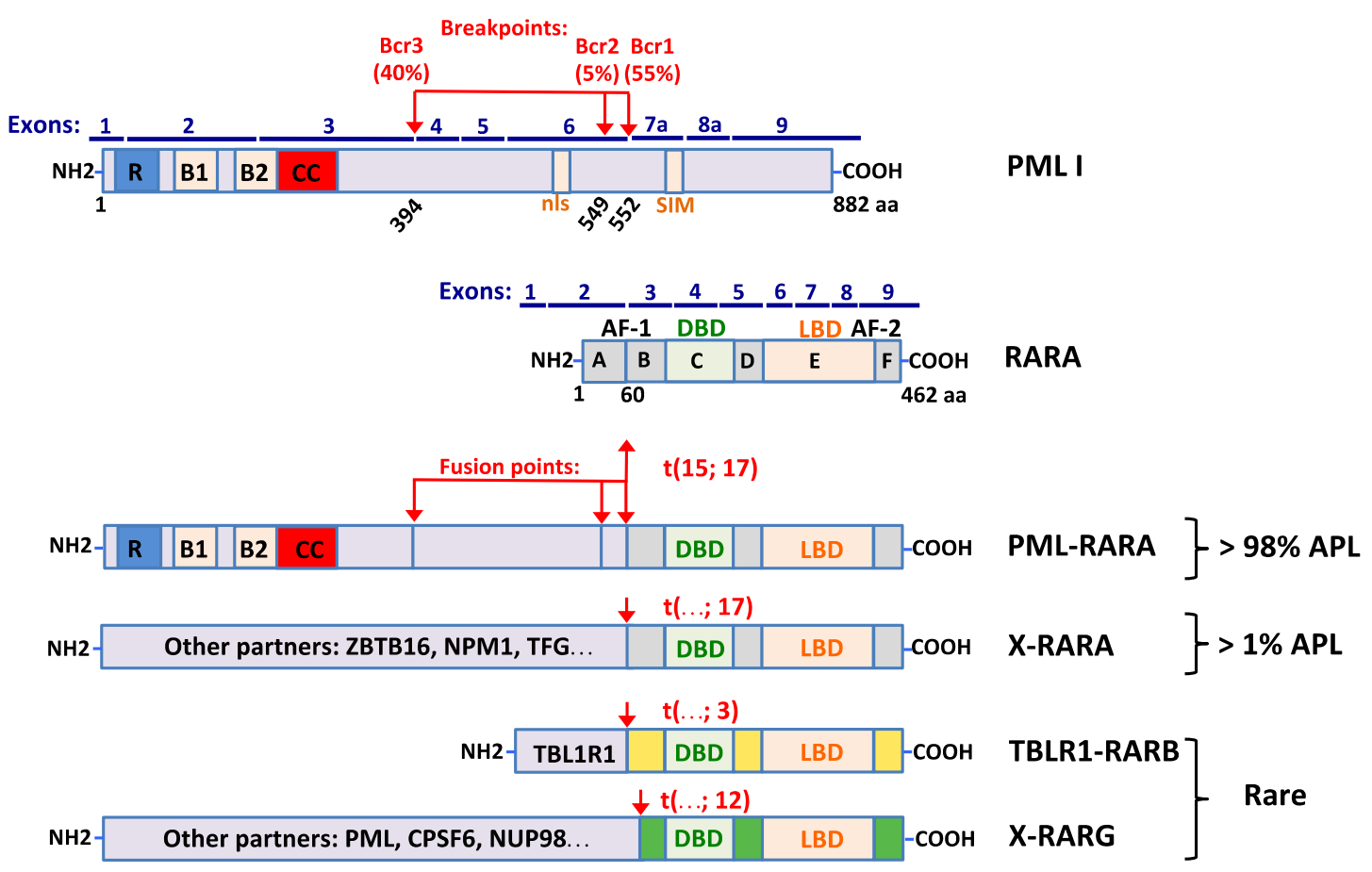

Figure 1. Structural organization of PML-RARA and other PML-independent RAR fusions in acute promyelocytic leukemia (APL) cells. Schematic representations of PML (isoform I), RARA and fusion partners of other retinoic acid receptors (RARB and RARG) before and after chromosomal rearrangements. Exons are shown in blue. The frequency of breakpoint cluster regions (Bcr) in APL is indicated in a percentage and fusion points are represented by a red arrow. The RING finger (R), B-boxes (B1 and B2), coiled-coil domain (CC), nuclear signal (nls) and sumo-interactif motif (SIM) in PML are represented by different colored boxes as well as functional domains in RARA: A-B: AF-1 transcriptional domain; C: DNA binding domain (DBD); D: hinge region; E: ligand binding domain (LBD), heterodimerization and AF-2 transactivation domain; F: unknown function.

\section{Current Understanding of Classic APL Pathogenesis and Treatment Response}

Pathogenesis of "classic" APLs was extensively reviewed elsewhere and will be only briefly summarized here. Fusion of PML to RARA yields an oncogenic transcription factor, which triggers both transcriptional deregulation of RARA and non-RARA target genes, together with disruption of PML nuclear bodies, the key regulators of senescence [10-12]. Multiple other features of PML-RARA were described, but their actual contributions to in vivo transformation remains unestablished. One of the most striking features of APL is its sensitivity to targeted therapies [6]. Indeed, APL has now become the most curable form of adult leukemia when treated by combined therapies with all trans-retinoic acid (ATRA) and arsenic trioxide (ATO). Clinical management of APL has been recently reviewed [13]. Major therapeutic advances were obtained in the '90s with the introduction of differentiation therapy with ATRA [14]. To avoid relapse that almost invariably occurs with ATRA monotherapy, ATRA plus anthracycline-based chemotherapy became the standard treatment for APL with complete remission rates to $90-95 \%$, but delayed relapses occurred in many patients. First line administration of ATO in combination with ATRA radically changed the prognosis of a fatal disease into a fully curable one, even without chemotherapy [15-18]. The urgent necessity to make ATO available in all countries, in particular the oral form, which has proven its clinical utility in multiple trials, should be stressed in that respect $[19,20]$.

ATRA acts at the transcriptional level to de-repress RARA target genes, yielding terminal differentiation of malignant promyelocytes into mature granulocytes [21]. Mechanistically, binding of ATRA to the RARA moiety of PML-RARA induces a conformational change that causes the dissociation of corepressors complexes and the recruitment of coactivators, activating gene re-expression. ATRA also 
acts on the stability of the PML-RARA protein by inducing its degradation in a proteasome-dependent manner, but also through proteolytic cleavage and autophagy-dependent mechanisms [22-24]. PML-RARA degradation per se results in the transcriptional reactivation of many differentiation genes, together with the reformation of PML nuclear bodies [25,26]. Arsenic binds directly onto specific cysteines residues located on zinc fingers, notably in the B2 domains of PML $[27,28]$. At therapeutic concentrations, ATO induces the sumoylation of both PML-RARA and PML, leading to their proteasomal degradation in an RNF4-dependant manner [29-31]. PML-RARA degradation by arsenic derepresses expression of differentiation genes, as well as allows reformation of PML nuclear bodies and restoration of senescence [32-35]. In addition, ATO targeting of the normal PML allele enforces NB nuclear bodies (NB) formation and contributes to therapy response. Indeed, mutations of the arsenic binding site of the unrearranged PML protein were discovered in therapy-resistant patients [36,37]. Thus, ATRA and ATO are targeted therapies directed onto the two constitutive moieties of the PML-RARA fusion. The dual targeting of PML-RARA (for destruction) and PML (for NB formation prior to catabolism) explains the potency of single agent arsenic for APL [6,38].

\section{Mutations that Cooperate with Deregulated RARA Signaling to Drive APL and/or Therapy Resistance}

Several recent studies have explored the gene mutations, which cooperate with PML-RARA to drive APL development or aggressiveness [39-44]. Many of these cooperating genes are also found in non-APL AMLs [42]. FLT3 is the most frequent mutation in APL, present in roughly one third of patients. Other genes recurrently mutated included WT1 (14\%), NRAS (10\%) and KRAS (4\%). MYC amplification through trisomy 8 is also frequent (12\% of cases). Advent of next generation sequencing (NGS) and whole exome sequencing of APL patients at diagnosis increased the variety of genetic alterations in APL, also demonstrating the existence of subclones [39,40,45]. Among new alterations, components of SWI/SNF complex, ARID1A (5\%) and ARID1B (3\%) genes were identified. Interestingly, genetic alterations commonly found in acute myeloid leukemia like DNMT3, TET2, NPM1, IDH1 or IDH2 are rarely detected, suggesting that PML-RARA exhibits a distinct transformation pathway among AML.

Mutations associated with relapse or therapy resistance have also been identified by these studies. Many mutations conferring resistance to ATRA or ATO are "on-target", inhibiting direct binding of these agents onto PML-RARA, formally demonstrating that these agents are targeted therapies [46-49]. More recently, mutations on the arsenic-binding site of the normal PML allele have also been reported, demonstrating the key role of the normal PML gene in ATO response [36]. More broadly, independent studies have reported that activation of potent oncogenes at diagnosis was associated with ATRA plus chemotherapy resistance [40,50]. One particular case is FMS-like tyrosine kinase 3 (FLT3), a receptor tyrosine kinase often mutated in AML. The most common mutations found in the internal tandem duplication (FLT3-ITD) region confers a high leukemic burden in APL and an adverse prognosis for patients treated by the ATRA/chemotherapy combination [51-53]. Recently, FLT3-ITD mutations were shown to severely blunt the ATRA response in animal models, precluding PML-RARA degradation and PML NB reformation [54], corroborating clinical studies. Yet, in mice models or patients, such resistance can be overcome by ATO, reinforcing the importance to use ATRA/ATO combination in high-risk APL patients with FLT3 mutations $[18,55,56]$.

\section{Novel Retinoic Acid Receptors Fusions in APL}

Since the discovery of PML-RARA, more than a dozen diverse translocations involving RARA have been found in rare leukemia patients, often with typical morphological features of APL [57-59]. More recently, very rare fusions involving other retinoic acid receptors have also been described (Table 1, Figure 2) [60]. These results broaden the spectrum of APL-associated fusions and have important impact for our understanding of pathogenesis and treatment response. 
Table 1. RAR partners causing APL and APL-like malignancies.

\begin{tabular}{|c|c|c|c|}
\hline Fusion Protein & Incidence & Cytogenetic & References (1st Report When >10 Cases) \\
\hline X-RARA & & & \\
\hline PML-RARA & $98 \%$ & $\mathrm{t}(15 ; 17)(\mathrm{q} 22 ; \mathrm{q} 21)$ & [2] \\
\hline ZBTB16-RARA & $1 \%$ & $\mathrm{t}(11 ; 17)(\mathrm{q} 23 ; \mathrm{q} 21)$ & [61] \\
\hline BCoR-RARA & 2 cases & $\mathrm{t}(\mathrm{X} ; 17)(\mathrm{p} 11 ; \mathrm{q} 21)$ & [62] \\
\hline FIP1L1-RARA & 2 cases & $\mathrm{t}(4 ; 17)(\mathrm{q} 12 ; \mathrm{q} 21)$ & {$[63,64]$} \\
\hline FNDC3B -RARA & 1 case & $\mathrm{t}(3 ; 17)(\mathrm{q} 26 ; \mathrm{q} 21)$ & {$[65]$} \\
\hline GTF2I-RARA & 1 case & $\mathrm{t}(7 ; 17)(\mathrm{q} 11 ; \mathrm{q} 21)$ & [66] \\
\hline IRF2BP2-RARA & 5 cases & $\mathrm{t}(1 ; 17)(\mathrm{q} 42 ; \mathrm{q} 21)$ & {$[67-71]$} \\
\hline NABP1-RARA & 1 case & $\mathrm{t}(2 ; 17)(\mathrm{q} 32 ; \mathrm{q} 21)$ & {$[72]$} \\
\hline NPM1-RARA & $\begin{array}{l}>10 \\
\text { cases }\end{array}$ & $\mathrm{t}(5 ; 17)(\mathrm{q} 35 ; \mathrm{q} 21)$ & [73] \\
\hline NuMA-RARA & 1 case & $t(11 ; 17)(q 13 ; q 21)$ & {$[74,75]$} \\
\hline PRKAR1A-RARA & 1 case & $\operatorname{del}(17)(q 21 q 24)$ & [76] \\
\hline STAT3-RARA & 2 cases & $\mathrm{t}(17 ; 17)(\mathrm{q} 21 ; \mathrm{q} 21)$ & [77] \\
\hline STAT5b-RARA & $\begin{array}{l}>10 \\
\text { cases }\end{array}$ & $\mathrm{t}(17 ; 17)(\mathrm{q} 21 ; \mathrm{q} 21)$ & [78] \\
\hline TBLR1-RARA $^{\text {a }}$ & 3 cases & $\mathrm{t}(3 ; 17)(\mathrm{q} 26 ; \mathrm{q} 21)$ & {$[79,80]$} \\
\hline $\begin{array}{c}\text { TFG-RARA } \\
\text { X-RARB }\end{array}$ & 1 case & $\mathrm{t}(3 ; 14 ; 17)(\mathrm{q} 12 ; \mathrm{q} 11 ; \mathrm{q} 21)$ & [81] \\
\hline $\begin{array}{l}\text { TBLR1-RARB * } \\
\text { X-RARG }\end{array}$ & 3 cases & $\mathrm{t}(3 ; 3)(\mathrm{q} 26 ; \mathrm{p} 24)$ & [82] \\
\hline CPSF6-RARG * & 5 cases & $\mathrm{t}(12 ; 12)(\mathrm{q} 13 ; \mathrm{q} 15)$ & [83-85] \\
\hline NPM1-RARG-NPM1 ${ }^{*}$,a & 1 case & ND & [86] \\
\hline NUP98-RARG & 3 cases & $\mathrm{t}(11 ; 12)(\mathrm{p} 15 ; \mathrm{q} 13)$ & [87-89] \\
\hline PML-RARG & 1 case & $\mathrm{t}(12 ; 15)(\mathrm{q} 13 ; \mathrm{q} 22)$ & [90] \\
\hline
\end{tabular}

ND: non-determined, ${ }^{*}$ Fusion identified by whole genome sequencing, RNA-sequencing and RT-PCR, ${ }^{a}$ cryptic insertion of RAR member within the partner gene (only in one case for TBLR1-RARA). 
A.

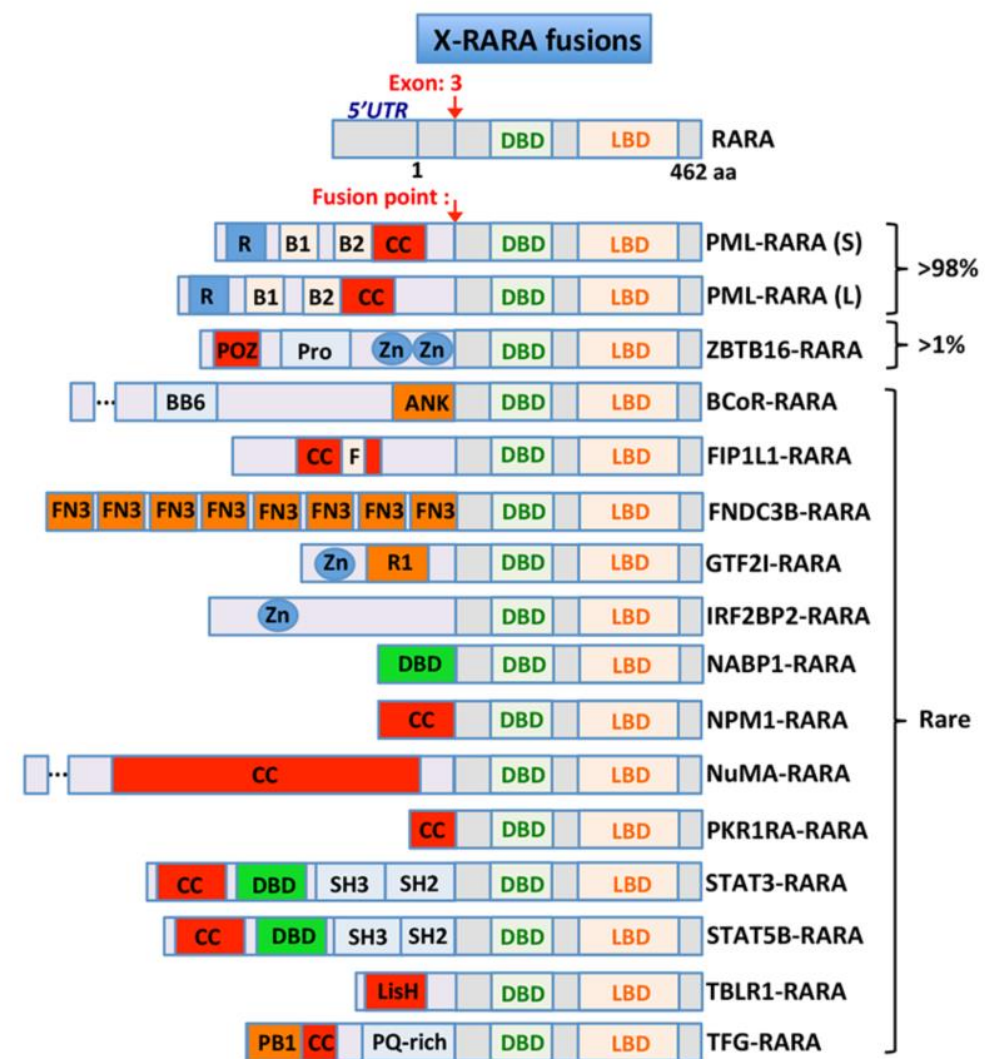

B.

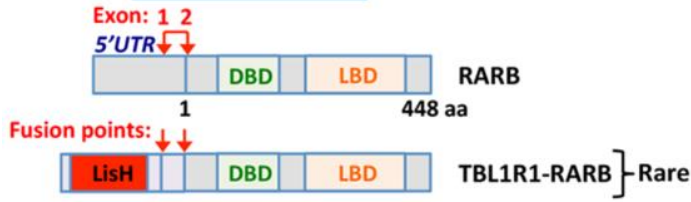

C.

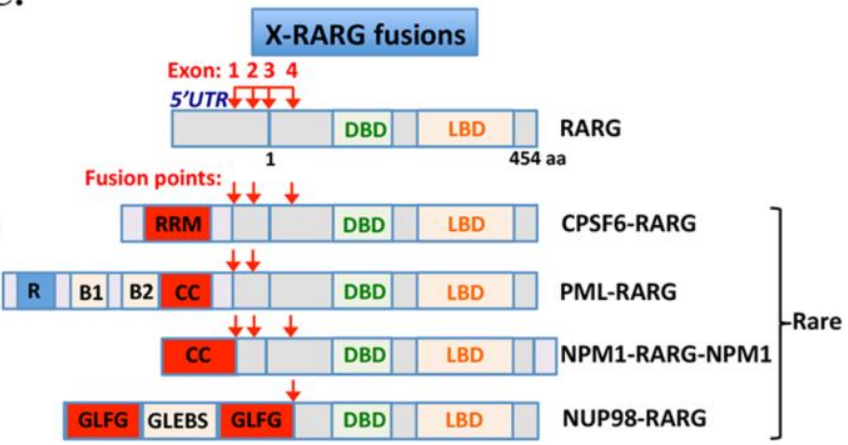

Figure 2. Schematic representation of the X-RARs fusions identified in APL: (A-C). Functional domains in X-RARA, X-RARB and X-RARG fusions proteins are represented by colored boxes. Exon and fusion points are indicated by a red arrow. Abbreviations: $5^{\prime}$-UTR: $5^{\prime}$ untranslated region; DBD: DNA binding domain; LBD: ligand binding domain; R: RING finger domain; B1 and 2: B box; CC: coiled-coil domain; POZ: BTB/POZ domain; Pro: proline-rich region; Zn: zinc finger domain; SH3: protein-protein interaction domain; $\mathrm{SH} 2$ : docking domain for phosphorylated tyrosine residues; BB6: Bcl6- binding domain; ANK: ankyrin repeats; F: FIP1 binding domain for polymerase; FN3: fibronectin 3 domain; R1: putative HLH motif; LisH: lissencephaly type-1-like homology motif; PB1: Phox and Bem1 domain; PQ-rich: proline-glutamine-enriched domain; RRM: RNA recognition motif; GLFG: Gly-Leu-Phe-Gly repeats; GLEBS: Gle2/ Rae1-binding sequence.

\subsection{PML-Independent RARA Fusions Involved in APL}

In the classic $\mathrm{t}(15,17)(\mathrm{q} 24 ; \mathrm{q} 21)$ with PML-RARA, the genomic breakpoint invariably occurred within the second intron of RARA. This led to in frame fusion with the PML gene (Figure 1). Similarly, in all others variants X-RARA translocations, partner genes $X$ were fused to exon 3 of RARA. Interestingly, a feature common to most RARA partners resides in the presence of a dimerization domain and/or a DNA binding domain [91]. These may promote homo and heterodimerization of 
RARA and facilitate and relax specificity of X-RARA/RXRA complex binding onto DNA [92-94]. Therefore, abnormal X-RARA/RXRA tetramers may compete with normal transcription factor to promote oncogenic signaling. Indeed, dominant-negative RARA mutants alter lineage development of progenitors [95]. We shall review fusion proteins associated with retinoic acid receptors in APL-like syndromes, but will not discuss three ways of rearrangements implicating PML, RARA and a third gene.

Epidemiology points to a single rate limiting event, e.g., PML-RARA fusion [96]. Yet, existence of cooperative events has been well established in "classic" APLs (see above), demonstrating that a functional hierarchy exists, with PML-RARA playing a central role and many other alterations facilitating leukemia "progression". Naturally, taken their rarity, cooperating events have not been well studied in variant APLs. In particular, any functional equivalent of the anti-senescence effects of PML disruption, if any, remain to be identified in those variants.

\subsubsection{ZBTB16-RARA $\mathrm{t}(11 ; 17)(\mathrm{q} 23 ; \mathrm{q} 21)$}

The zinc finger and BTB domain containing 16 (BTB16), previously named PLZF, is a transcriptional factor involved in self-renewal and differentiation of stem cells [97]. This is the most frequent variant partner of X-RARA fusions, found in approximately $1 \%$ of APL patients. The N-term part of ZBTB16 (including the BTB/POZ domain and two Zn fingers) become fused to the DNA and ligand binding domains of RARA [61]. Reciprocal proteins RARA-ZBTB16 (comprising zinc fingers of ZBTB16 implicated in DNA-binding) are expressed and may contribute to leukemogenesis [98,99]. ZBTB16-RARA avidly recruits repressors such as SMRT, N-Cor and HDACs to repress RARA targets and block myeloid differentiation.

It was recognized early on that patients with ZBTB16-RARA fusions do not respond to ATRA or ATO [100]. Yet, at the molecular level, ATRA degrades the ZBTB16-RARA fusion, demonstrating that oncoprotein loss is not sufficient for differentiation or clinical response [33,34,101,102]. It was proposed that reciprocal RARA-ZBTB16 proteins confer some ATRA resistance by inducing upregulation of CRABPI, a retinoic acid binding protein involved in catabolism of retinoids [99]. Some clinical benefit was obtained when combining ATRA to other agents, including G-CSF or histone deacetylase inhibitors [103-106].

\subsubsection{BCoR-RARA $t(X ; 17)(\mathrm{p} 11 ; \mathrm{q} 21)$}

The BCL6 corepressor (BCOR) is involved in multiple lymphomas $[107,108]$. BCOR is also a partner of PCGF1, a member of the noncanonical polycomb repressive complex 1 (PRC1.1). In BCOR-RARA fusion, the exon 3 of RARA is fused in frame with the first 12 exons of BCOR including the BCL6 binding domain. No reciprocal RARA-BCOR transcripts were detected. Two patients reached remission with an ATRA-chemotherapy regimen, including blast differentiation and one of them received ATO without any success at relapse [62,109].

\subsubsection{FIP1L1-RARA $\mathrm{t}(4 ; 17)(\mathrm{q} 12 ; \mathrm{q} 21)$}

The FIP1-like 1 (FIP1L1) encodes a subunit of the CPSF (cleavage and polyadenylation specificity factor) complex. FIP1L1 may be implicated in leukemogenic fusion genes, notably in chronic eosinophilic leukemia where it may become fused with platelet-derived growth factor receptor alpha (PDGFRA) [110]. In the two patients where chimeric FIP1L1-RARA proteins were identified, the first 13 or 15 exons of FIP1L1 (including a homodimerization domain) were fused to RARA. FIP1L1-RARA functions as a transcriptional repressor in vitro and homodimerization of FIP1L1-RARA may be required [111]. In addition, the reciprocal RARA-FIP1L1 fusion gene was detected in both patients. The first patient achieved a complete remission by oral ATRA alone [63], while the second died of differentiation syndrome during induction therapy with ATRA [64]. 


\subsubsection{FNDC3B-RARA $t(3 ; 17)(\mathrm{q} 26 ; \mathrm{q} 21)$}

The FNDC3B (Fibronectin Type III Domain Containing 3B) is a regulator of adipocyte differentiation [112] and cell migration [113]. In APL, the first 24 exons of FNDC3B containing 8 fibronectin 3 (FN3) domains are fused in frame with RARA. FNDC3B-RARA fusion protein acts as a potent repressor on RARA targets genes. Two reciprocal RARA-FNDC3B transcripts were also detected. A unique patient with APL received ATRA and quickly developed the differentiation syndrome [65]. Addition of chemotherapy achieved complete morphological remission. Thus, ATRA can initiate in vivo differentiation of this APL-like syndrome.

\subsubsection{GTF2I-RARA $t(7 ; 17)(\mathrm{q} 11 ; \mathrm{q} 21)$}

The general transcription factor TFII-I (GTF2I) is an essential and pleiotropic transcriptional regulator whose defects are associated with neurodevelopmental defects and several types of cancers [114]. In APL, the translocation involving GTF2I and RARA creates a fusion between RARA exon 3 and the first 6 exons of GTF2I, including a leucine zipper (LZ) and putative helix-loop-helix (HLH). No reciprocal RARA-GTF2I transcript was detected. This unique patient received ATRA, which transiently improved coagulopathy but did not initiate morphological differentiation of leukemic blasts [66] followed by an ATRA-combined chemotherapy. The patient received then a combination of ATRA /ATO without any benefit. Upregulation of the RING finger protein 8 (RNF8) in GTF2I-RARA transfected cells was proposed to favor ATRA resistance [115].

\subsubsection{IRF2BP2-RARA $\mathrm{t}(1 ; 17)(\mathrm{q} 42 ; \mathrm{q} 21)$}

Interferon regulatory factor 2 (IRF2) binding protein 2 (IRF2BP2) is a nuclear protein interacting with IRF2, a transcription factor involved in innate immunity [116]. IRF2BP2 zinc finger domain is fused with RARA exon 3 and reciprocal RARA-IRF2BP2 transcript could not be detected. IRF2BP2-RARA promotes immortalization of primary hematopoietic progenitors, which is abrogated with ATRA [67]. Among the five patients diagnosed with IRF2BP2-RARA APL-like syndrome, one was resistant to different treatments including ATRA alone [68]. Three patients showed a complete remission with ATRA-containing chemotherapy regimen [69-71]. Another one achieved differentiation and complete remission when ATRA was given as a single agent at diagnostic [67].

\subsubsection{NABP1-RARA $\mathrm{t}(2 ; 17)(\mathrm{q} 32 ; \mathrm{q} 21)$}

The nucleic acid binding protein 1 (NABP1), previously named OBFC2A, encodes a single-stranded DNA binding protein domain involved in genomic stability [117]. In the context of the fusion, the first five exons of NABP1 including its DNA binding domain are fused to RARA exon 3 . The unique patient reached complete remission with ATRA and chemotherapy, with some suggestions for differentiation induction [72].

\subsubsection{NPM-RARA $\mathrm{t}(5 ; 17)(\mathrm{q} 35 ; \mathrm{q} 21)$}

Nucleophosmin (NPM1) is a nucleolar phosphoprotein involved in the pathogenesis of several hematological malignancies, including non-Hodgkin lymphomas where NPM1 is a frequent translocation partner of the anaplastic lymphoma receptor tyrosine kinase (ALK) gene or AMLs where hotspot mutations of NPM1 delocalize the protein to the cytoplasm and block differentiation [118,119]. In APL, the first four exons of NPM1 including a hydrophobic oligomerization domain are fused to RARA exon 3 [73]. Reciprocal proteins RARA-NPM1 fusion proteins were also reported, but do not affect myeloid differentiation in cell culture [120]. NPM1 is a haplo-insufficient gene, so that loss of one allele may contribute to neoplastic transformation [121].

Among the dozen patients with NPM1-RARA, many are pediatric cases [73,122-125]. While they received induction with an ATRA-chemotherapy combination, most of them relapsed. Two patients received ATRA alone: one of them died of differentiation syndrome [123] and the other achieved 
complete remission prior to consolidation chemotherapy [126]. A rare case of atypical acute myelomonocytic leukemia was also reported [127], where ATRA combined to chemotherapy allowed durable remission. Thus, NPM1 fusions seem to exhibit significant ATRA-sensitivity.

\subsubsection{NuMA-RARA $\mathrm{t}(11 ; 17)(\mathrm{q} 13 ; \mathrm{q} 21)$}

The nuclear mitotic apparatus protein 1 (NuMA) is an essential component for the formation and the maintenance of mitotic spindle poles during mitosis [128]. The first 20 exons of $N u M A$ (including a long coiled-coil domain and a spindle binding domain) are fused to RARA [74]. No reciprocal RARA-NuMA proteins were detected. The unique patient achieved complete remission with ATRA [75].

\subsubsection{PRKAR1A-RARA t(17; 17)(q21; q24) or del(17)(q21q24)}

The PRKAR1A gene encodes the regulatory subunit type I $\alpha(\mathrm{RI} \alpha)$ of the cAMP-dependent protein kinase A (PKA). Its aberrant signaling leads to multiple skin abnormalities, diverse tumors and also infertility [129]. PRKAR1 harbors a dimerization domain, which is fused to the DNA and ligand binding regions of RARA, as in others X-RARA translocations. Nevertheless, similar to STAT5B [130], dimerization domain of PRKAR1A is dispensable for transformation of murine myeloid progenitors [131]. Clinically, the unique patient shows a good clinical response to ATRA/chemotherapy [76].

\subsubsection{STAT5b-RARA t(17; 17)(q21; q21) or dup(17)(q12q21)}

The signal transducer and activator of transcription (STAT5b) belong to a family of latent cytosolic transcription factors activated by cytokines or growth factors [132]. STAT5 is constitutively activated through multiple mechanisms during hematological transformation. In rare APL-like syndromes, the first 14, 15 or 16 exons of STAT5B (including coiled-coil, DNA binding and SH3/SH2 domains) are fused to RARA. No reciprocal RARA-STAT5b transcripts were found. At least 10 patients harboring STAT5B-RARA protein were reported with classic APL features [78,133-138]. Disease remained incentive to ATRA. No APL differentiation was observed with ATRA or ATO, while an ATRA and decitabine combination showed some response [139] so that this disease remains a therapeutic challenge [138].

\subsubsection{STAT3-RARA $\mathrm{t}(17 ; 17)(\mathrm{q} 21 ; \mathrm{q} 21)$ or dup(17)(q12q21)}

The signal transducer and activator of transcription 3 (STAT3) are phosphorylated in response to cytokines and growth factors [132]. Similar to STAT5 fusions, coiled-coil, DNA binding domains and SH3/SH2 domains of STAT3 are fused to RARA. Clinically, the two patients reported were totally insensitive to ATRA and/or ATO treatment, even when combined to chemotherapy [77].

\subsubsection{TBLR1-RARA $\mathrm{t}(3 ; 17)(\mathrm{q} 26 ; \mathrm{q} 21)$}

The transducin beta-like protein 1 (TBL1, also known as TBL1X) and its related gene (TBLR1, also known as TBL1XR1) are two exchange factors of NCoR/SMRT corepressors that regulate transcription [140]. For TBLR1-RARA chimeric proteins, the first five exons of TBLR1 containing a LisH domain required for its dimerization were fused to RARA in two patients [79]. No reciprocal RARA-TBLR1 proteins were detected in patients. One of the two patients received ATRA-combined chemotherapy as induction treatment, which was interrupted because of toxicity. However, complete remission with an ATO and mitoxantrone combination was subsequently achieved [79]. A cryptic insertion of RARA (exon 3 to exon 9) was found between exon 5 and exon 6 of TBLR1 gene in a pediatric case [80]. This patient did not respond to an induction therapy with ATRA alone. TBLR1 was also identified as a translocation partner of RARB (see below). 


\subsubsection{TFG-RARA $\mathrm{t}(3 ; 14 ; 17)(\mathrm{q} 12 ; \mathrm{q} 11 ; \mathrm{q} 21)$}

The tropomyosin-receptor kinase fused gene (TRK-fused gene, TFG) is a regulator of protein secretion [141]. TFG may be associated with lymphoma when fused with the ALK gene [142]. In APL, a complex chromosomal rearrangement creates a fusion between RARA exon 3 and the first 7 exons of TFG gene including a PB1 protein-protein-interaction domain and a coiled-coil motif. A unique patient with hypergranular morphotype showed a high sensitivity to ATRA alone reaching complete remission [81].

\subsection{RARB and RARG Fusions Involved in APL-Like Leukemias}

Two other members of the retinoic acid receptor superfamily ( $R A R B$ and $R A R G$ ) have now also been involved in leukemogenesis (Figures 1 and 2, Table 1). All three receptors share a high sequence homology but have distinct transcriptional properties and expression patterns. Extensive studies in mice have pointed to some in vivo redundancy [143,144]. In hematopoiesis, RARA plays an important role on myeloid differentiation, while RARG is an important contributor of stem cell maintenance or inflammatory cytokine production [145]. When fused with PML all RARs members showed a similar oncogenic activity in in vitro assays [146]. However, as detailed below, unlike X-RARA fusion, most AML patients with RARG-rearrangement showed distinct clinical resistance to ATRA.

\subsubsection{TBLR1-RARB $\mathrm{t}(3 ; 3)(\mathrm{q} 26 ; \mathrm{q} 24)$}

TBLR1 gene, involved in rare TBLR1-RARA fusions, is also a translocation partner of RARB in APL. The same N-terminal part of TBLR1 is fused to $R A R B$ exon 2 [82]. All patients were not only resistant to ATRA, but also to polychemotherapy.

\subsubsection{CPSF6-RAR $\gamma \mathrm{t}(12 ; 12)(\mathrm{q} 13 ; \mathrm{q} 15)$}

The cleavage and polyadenylation specific factor 6 (CPSF6) is a subunit of an RNA-binding protein complex. Different types of CPSF6-RARG fusion transcripts were found by whole genome sequencing or RNA-sequencing in five patients. All harbor the first four exons of CPSF6 including a RNA recognition motif (RRM) fused in frame to either 5'UTR or exon 4 of RARG [83-85,147]. None of the patients did not show any ATRA sensitivity. The first one received ATRA and ATO followed by induction chemotherapy but died 37 days after diagnosis [84]. The two other cases report diagnosed with CPSF6-RARG showed also resistance to induction treatment with ATRA or ATRA plus arsenic $[83,147]$. Very recently, sensitivity of CPSF6-RARG to homoharringtonine and chemotherapy was reported in one patient [85].

\subsubsection{The NPM1-RARG-NPM1 (Karyotype Non-Determined)}

The NPM1 gene, already reported as a translocation partner of RARA, was also recently identified as a fusion partner of $R A R G$ [86]. Multiplex reverse transcription polymerase chain reaction (RT-PCR) and whole genome sequencing revealed insertion of RARG (5'UTR-exon9) within the NPM1 gene to yield NPM1-RARG-NPM1 chimeric proteins. Partial deletion of RARG exon 10 causes a loss of 25 aa in the ligand binding domain of RARG that may impair ATRA binding, while the critical tryptophan residues implicated in NPM1 nucleolar targeting are also altered. The unique patient was resistant to ATRA and ATO.

\subsubsection{NUP98-RARG $\mathrm{t}(11 ; 12)(\mathrm{p} 15 ; \mathrm{q} 13)$}

NUP98 is a nucleoporin fused to a variety of partners in diverse myeloid and lymphoid malignancies [148]. All NUP98 fusions involve N-terminal GLFG repeats (for Gly-Leu-Phe-Gly) including a binding site for the mRNA export mediator Gle2/ Rae1 (GLEBS domain) that provide a docking site for nucleocytoplasmic transport of RNA and protein. In the context of its fusion with $R A R G$, the first 12 exons of NUP98 are fused in frame with $R A R G$ exon 4 , without reciprocal 
fusion products. Ex vivo transformation assays revealed that both GLFG repeats and DNA binding domain in RARG were required for the oncogenic activity of the chimeric protein [149]. ATRA or RXR agonists suppress transformation properties of NUP98-RARG in vitro and in vivo assays. Among the three patients reported to date, the first one had ATRA treatment for one day before chemotherapy initiation [87]. The two others patients $[88,89]$ received ATRA/ATO without any success.

\subsubsection{PML-RARG $\mathrm{t}(12 ; 15)(\mathrm{q} 13 ; \mathrm{q} 22)$}

A unique translocation $\mathrm{t}(12 ; 15)(\mathrm{q} 13 ; \mathrm{q} 22)$ involving $P M L$ and $R A R G$ was reported in one case. Fusion breakpoints occurred within intron 3 of PML (like those observed in PML-RARA bcr3 fusions) and the $5^{\prime}$ untranslated region (UTR) of RARG. The unique patient with clinical features of classical APL received ATRA treatment for 9 days, but did not exhibit a differentiation [90]. Chemotherapy drove complete remission. ATO sensitivity was not documented. Overall, ATRA response was impossible to document in this setting.

\subsection{Available Data for Therapy Response in Variant APLs}

Constant involvement of RARA or other retinoic acid receptor super family members stresses the importance of deregulated retinoic acid signaling in driving APL pathogenesis. A key point is that therapy response is substantially different from that of classic APL, with inconsistent ATRA-sensitivity, but consistent ATO-resistance. Results from mouse studies have clearly outlined different types of responses to ATRA or ATO (differentiation and loss of self-renewal) corresponding to distinct molecular mechanisms. These often temporally overlap and synergize to enforce eradication of classic APL $[6,33,34]$. The first type of response is differentiation, driven by transcriptional reactivation of PML-RARA-silenced target genes. PML-RARA destruction (for example by ATO or shRNA) can similarly induce differentiation through promoter clearance [26]. However, differentiation is clearly not sufficient for the success of APL therapy [21]. Even AML dedifferentiation may occur and explain clinical relapses [150]. Apart from differentiation, a mechanistically distinct consequence of therapy is loss of APL self-renewal [33-35]. Clinically, this is reflected by a decrease in the burden of leukemic cells, restoration of normal hematopoiesis and eradication of the APL clone driving long-term survival. In classic APL, this is associated to restoration of PML nuclear bodies, well-known regulators of senescence, upon PML-RARA destruction [25,32].

Unlike PML-RARA, most of the novel retinoic acid receptors fusions associated with APL are clinically resistant to ATRA or ATO (Table 2). This is expected for ATO, which targets PML [32,151,152], but is more complex for ATRA. This reinforces the model that PML-driven senescence, initiated by PML-RARA degradation or arsenic targeting of PML, is an important contributor to a long-term clinical response [6,33]. Although clinical features and molecular characteristics of RAR partners are usually well documented for each case report, lack of information about blast decrease or differentiation upon ATRA or ATO treatments often precludes firm conclusions to be drawn, to mechanistically understand therapeutic failure. Moreover, it is not always easy to monitor APL differentiation and progressive clearance or to decipher the contribution of each mechanism to the therapy response. Naturally, as soon as targeted therapies are coupled with "classic" AML drugs (chemotherapy, demethylating agents and bone marrow transplantation) it becomes almost impossible to assess the contribution of ATRA or ATO, except if the clinical issue is rapidly fatal. 
Table 2. ATRA/ATO therapy response for X-RARs fusions.

\begin{tabular}{|c|c|c|c|c|c|}
\hline Fusion Protein & $\begin{array}{c}\text { ATRA } \\
\text { Response }\end{array}$ & $\begin{array}{c}\text { ATO } \\
\text { Response }\end{array}$ & $\begin{array}{c}\text { Blast } \\
\text { Decrease }\end{array}$ & $\begin{array}{c}\text { Blast } \\
\text { Differentiation }\end{array}$ & $\begin{array}{c}\text { Self-Renewal of } \\
\text { Bone Marrow }\end{array}$ \\
\hline \multicolumn{6}{|l|}{ X-RARA } \\
\hline PML-RARA & Sensitive & Sensitive & Yes & Yes & Yes \\
\hline ZBTB16-RARA * & Resistant & Resistant & Yes & Yes & No \\
\hline BCoR-RARA & Resistant & Resistant & ND & Yes $^{a}$ & ND \\
\hline FIP1L1-RARA & Sensitive $^{a}$ & ND & Yes $^{a}$ & Yes $^{a}$ & Yes $^{a}$ \\
\hline FNDC3B-RARA & Uncertain & ND & No & Yes $^{a}$ & No \\
\hline GTF2I-RARA & Resistant & Resistant & No & No & No \\
\hline IRF2BP2-RARA & Likely & Resistant & No & Yes $^{a}$ & Yes $^{a}$ \\
\hline NABP1-RARA * & Uncertain & ND & No & Yes & ND \\
\hline NPM1-RARA & Sensitive & ND & Yes & Yes & Yes \\
\hline NuMA-RARA & Likely & ND & ND & Yes & ND \\
\hline PRKAR1A-RARA & Uncertain & Uncertain & ND & Yes & ND \\
\hline STAT3-RARA & Resistant & Resistant & No & No & ND \\
\hline STAT5b-RARA & Resistant & Resistant & No & No & No \\
\hline TBLR1-RARA & Resistant & Resistant & No & No & No \\
\hline TFG-RARA & Sensitive & ND & Yes & ND & Yes \\
\hline \multicolumn{6}{|l|}{ X-RARB } \\
\hline TBLR1-RARB & Resistant & $\mathrm{ND}$ & No & No & No \\
\hline \multicolumn{6}{|l|}{ X-RARG } \\
\hline CPSF6-RARG & Resistant & Resistant & No & No & No \\
\hline NPM1-RARG-NPM1 & Resistant & Resistant & No & No & No \\
\hline NUP98-RARG & Resistant & Resistant & No & No & No \\
\hline PML-RARG & Resistant & ND & ND & No & ND \\
\hline
\end{tabular}

* ZBTB16-RARA (PLZF-RARA); NABP1-RARA (OBFC2A/RARA). ND: Non-determined; a (in 1 case). Uncertain: ATRA treatment combined with additional chemotherapy and/or stem cell transplantation.

\section{Are New Genetic Findings of APL-Like AMLs Shedding A New Light in Its Pathogenesis?}

First, the variant APL-like associated translocation evidently points to the role of deregulated retinoid signaling at large in leukemia initiation. Significant evidence also points to enhanced repression and silencing of genes as a central and directly causative mechanism. Indeed, the most commonly affected retinoic acid receptor member, $R A R A$, similar to the thyroid hormone receptors, is well known to bind more avidly corepressors than the two other members [153]. Then, ATRA dissociated the repressive SMRT/SIN/HDAC complex and allows recruitment of coactivators, so that the RARA ATRA couple behaves as molecular switch, with the ability to be repressive, neutral or activating. Second, variant fusions often contain identified repressive domains, very well characterized in the case of ZBTB16 [154]. Similarly, the proposed central role of a dimerization domain provided by the fusion partner, remains to be experimentally substantiated for most APL-like syndromes [155], although it was suggested for some, such as FIP1L1-RARA. Ultimately, the nature and the respective importance of downstream target genes repressed by the RARA fusions remain largely unknown.

In trying to understand the physiopathology of variant translocations, one should not forget the literature linking myeloid differentiation to retinoic acid signaling and normal RARA. The historical model of ATRA-induced differentiation, HL60, exhibits RARA haplo-insufficiency, but no other genetic alteration [156]. Thus, fusions of $R A R A$ are not required for ATRA-induced differentiation 
and growth arrest of some AMLs. Conversely, ATRA-resistant HL60 mutants harbor mutations in RARA [157]. RARA regulates the normal differentiation of promyelocytes delaying it in RARA absence and accelerating it in the presence of ATRA [158]. Accordingly, dominant negative forms of RARA block myeloid differentiation of progenitors [95]. Actually, even overexpression of normal RARA induced blocks progenitors' differentiation at the promyelocytic stage and promotes self-renewal [159]. Finally, recent studies in human AMLs have correlated the presence of RARA-associated super-enhancers to ATRA-induced differentiation [160]. This suggests that in the clinical setting, some AMLs exhibiting high RARA levels and critical RARA-associated transcriptional super-enhancer confers susceptibility to ATRA-induced differentiation. It is possible that this RARA super-enhancer is also linked to AML initiation. In that sense, addition of ATRA to chemotherapy in non-APL AMLs was proposed to have some clinical benefit [161,162]. Collectively, these observations highlight a complex and ill-understood relationship between retinoic acid signaling, normal myeloid differentiation, leukemic transformation and a potential benefit of ATRA signaling in AML cells, where RARA-mediated basal repression of retinoic acid signaling or its ATRA-triggered activation, seem to be a central theme, independently from fusion proteins.

While pathogenesis of classic APL clearly involves RARA- and PML-dependent features, it is possible that pathogenesis of some APL-like syndromes associated with rare X-RARA fusions is more closely related to immortalization by RARA overexpression [159], possibly not even requiring homodimerization through partner $X$. Indeed, basal RARA expression is low and the translocations not only fuse two genes, but also put the downstream gene under the control of the upstream gene promoter. In some cases, such as NPM1, these are very strong promoters [163], predicting supra-physiological levels of X-RARA expression, in contrast to PML-RARA. This may explain why some of these patients responded well to ATRA. Indeed, in either RARA-overexpressing cells or AML with RARA-associated super-enhancers, ATRA has a significant impact for survival or clonogenic activity $[40,94,160]$. Overall, we propose a working model wherein retinoic acid signaling has to reach a certain threshold to oppose transformation imposed by RARA overexpression or X-RARs fusion with fusion-acquired repressive properties. Note that some patients with classic APL were cured by retinoic acid alone, particularly with the liposomal form [164]. Since ATRA is expected to initiate degradation of any X-RARs fusion [23,101], it should probably be considered in the clinical management of any of the syndromes, because it should sharply down-regulate the steady state level of the oncogenic driver. Combinations, at least with classic chemotherapy, represents an attractive option, although demethylating agents or proapoptotic Bcl2 antagonists may also show some efficacy.

\section{Conclusions: Deregulated Retinoic Acid Signaling in Other Malignancies?}

Interestingly, recent studies have highlighted the existence of mutations of RARA, independently from its fusions, in other conditions [165], including rare subtypes of breast cancers [166]. Clinically, ATRA was proposed to enhance the efficacy of chemotherapy in AMLs, particularly in those bearing a mutation in NPM1 [161,162]. Several possible mechanisms where proposed, including NPM1c degradation [167,168] or interference with mutant IDH-mediated high ROS levels [169,170]. Finally, ATRA -and to a lesser extend ATO- were proposed to inhibit Pin-1, an enzyme implicated in the progression of multiple cancer types [169,171,172]. Clearly, any evidence for ATRA-reversible deregulation of retinoid signaling in other settings than APL could have considerable impact for patient care. Interestingly, some related findings were recently reported with vitD3 and its receptor [173]. Thus, links between nuclear receptor signaling and cancer is likely to be broader than the narrow example of APL and related APL-like diseases.

Funding: The H.d.T. laboratory is supported by the Ligue Nationale contre le Cancer, INSERM, Centre National de la Recherche Scientifique, University Paris Diderot, Institut National du Cancer, the Association pour la Recherche contre le Cancer (Prix Griffuel), European Research Council Senior grant 268729-STEMAPL (to H.d.T.), and TRANSCAN (DRAMA project).

Conflicts of Interest: The authors declare no conflict of interest. 


\section{References}

1. Dinmohamed, A.G.; Visser, O. Incidence of acute promyelocytic leukemia across Europe: Results of RARECAREnet-a population-based study. Stem Cell Investig. 2019, 6, 37. [CrossRef] [PubMed]

2. De The, H.; Chomienne, C.; Lanotte, M.; Degos, L.; Dejean, A. The t(15;17) translocation of acute promyelocytic leukaemia fuses the retinoic acid receptor alpha gene to a novel transcribed locus. Nature 1990, 347, 558-561. [CrossRef]

3. De Thé, H.; Lavau, C.; Marchio, A.; Chomienne, C.; Degos, L.; Dejean, A. The PML-RAR alpha fusion mRNA generated by the $\mathrm{t}(15 ; 17)$ translocation in acute promyelocytic leukemia encodes a functionally altered RAR. Cell 1991, 66, 675-684. [CrossRef]

4. Borrow, J.; Goddart, A.; Sheer, D.; Solomon, E. Molecular analysis of acute promyelocytic leukemia breakpoint cluster region on chromosome 17. Science 1990, 249, 1577-1580. [CrossRef] [PubMed]

5. Longo, L.; Pandolfi, P.; Biondi, A.; Rambaldi, A.; Mencarelli, A.; Lo Coco, F.; Diverio, D.; Pegoraro, L.; Avanzi, G.; Tabilio, A.; et al. Rearrangement and aberrant expression of the retinoic acid receptor a gene in acute promyelocytic leukemia. J. Exp. Med. 1990, 172, 1571-1575. [CrossRef]

6. De The, H.; Pandolfi, P.P.; Chen, Z. Acute Promyelocytic Leukemia: A Paradigm for Oncoprotein-Targeted Cure. Cancer Cell 2017, 32, 552-560. [CrossRef] [PubMed]

7. Dos Santos, G.A.; Kats, L.; Pandolfi, P.P. Synergy against PML-RARa: Targeting transcription, proteolysis, differentiation, and self-renewal in acute promyelocytic leukemia. J. Exp. Med. 2013, 210, 2793-2802. [CrossRef] [PubMed]

8. Noguera, N.I.; Catalano, G.; Banella, C.; Divona, M.; Faraoni, I.; Ottone, T.; Arcese, W.; Voso, M.T. Acute Promyelocytic Leukemia: Update on the Mechanisms of Leukemogenesis, Resistance and on Innovative Treatment Strategies. Cancers 2019, 11, 1591. [CrossRef] [PubMed]

9. Arber, D.A.; Orazi, A.; Hasserjian, R.; Thiele, J.; Borowitz, M.J.; Le Beau, M.M.; Bloomfield, C.D.; Cazzola, M.; Vardiman, J.W. The 2016 revision to the World Health Organization classification of myeloid neoplasms and acute leukemia. Blood 2016, 127, 2391-2405. [CrossRef]

10. Sahin, U.; de The, H.; Lallemand-Breitenbach, V. PML nuclear bodies: Assembly and oxidative stress-sensitive sumoylation. Nucleus 2014, 5, 499-507. [CrossRef]

11. Sahin, U.; Lallemand-Breitenbach, V.; de The, H. PML nuclear bodies: Regulation, function and therapeutic perspectives. J. Pathol. 2014, 234, 289-291. [CrossRef] [PubMed]

12. Vernier, M.; Bourdeau, V.; Gaumont-Leclerc, M.F.; Moiseeva, O.; Begin, V.; Saad, F.; Mes-Masson, A.M.; Ferbeyre, G. Regulation of E2Fs and senescence by PML nuclear bodies. Genes Dev. 2011, 25, 41-50. [CrossRef] [PubMed]

13. Sanz, M.A.; Fenaux, P.; Tallman, M.S.; Estey, E.H.; Lowenberg, B.; Naoe, T.; Lengfelder, E.; Dohner, H.; Burnett, A.K.; Chen, S.J.; et al. Management of acute promyelocytic leukemia: Updated recommendations from an expert panel of the European LeukemiaNet. Blood 2019, 133, 1630-1643. [CrossRef]

14. Degos, L.; Dombret, H.; Chomienne, C.; Daniel, M.T.; Miclea, J.M.; Chastang, C.; Castaigne, S.; Fenaux, P. All-trans retinoic acid as a differentiating agent in the treatment of acute promyelocytic leukemia. Blood 1995, 85, 2643-2653. [CrossRef] [PubMed]

15. Estey, E.; Garcia-Manero, G.; Ferrajoli, A.; Faderl, S.; Verstovsek, S.; Jones, D.; Kantarjian, H. Use of all-trans retinoic acid plus arsenic trioxide as an alternative to chemotherapy in untreated acute promyelocytic leukemia. Blood 2006, 107, 3469-3473. [CrossRef] [PubMed]

16. Lo-Coco, F.; Avvisati, G.; Vignetti, M.; Thiede, C.; Orlando, S.M.; Iacobelli, S.; Ferrara, F.; Fazi, P.; Cicconi, L.; Di Bona, E.; et al. Retinoic acid and arsenic trioxide for acute promyelocytic leukemia. N. Engl. J. Med. 2013, 369, 111-121. [CrossRef] [PubMed]

17. Lo-Coco, F.; Di Donato, L.; Schlenk, R.F. Targeted Therapy Alone for Acute Promyelocytic Leukemia. N. Engl. J. Med. 2016, 374, 1197-1198. [CrossRef] [PubMed]

18. Burnett, A.K.; Russell, N.H.; Hills, R.K.; Bowen, D.; Kell, J.; Knapper, S.; Morgan, Y.G.; Lok, J.; Grech, A.; Jones, G.; et al. Arsenic trioxide and all-trans retinoic acid treatment for acute promyelocytic leukaemia in all risk groups (AML17): Results of a randomised, controlled, phase 3 trial. Lancet Oncol. 2015, 16, 1295-1305. [CrossRef]

19. Zhu, H.H.; Hu, J.; Lo-Coco, F.; Jin, J. The simpler, the better: Oral arsenic for acute promyelocytic leukemia. Blood 2019, 134, 597-605. [CrossRef] 
20. Zhu, H.H.; Wu, D.P.; Du, X.; Zhang, X.; Liu, L.; Ma, J.; Shao, Z.H.; Ren, H.Y.; Hu, J.D.; Xu, K.L.; et al. Oral arsenic plus retinoic acid versus intravenous arsenic plus retinoic acid for non-high-risk acute promyelocytic leukaemia: A non-inferiority, randomised phase 3 trial. Lancet Oncol. 2018, 19, 871-879. [CrossRef]

21. De The, H. Differentiation therapy revisited. Nat. Rev. Cancer 2018, 18, 117-127. [CrossRef] [PubMed]

22. Nervi, C.; Ferrara, F.F.; Fanelli, M.; Rippo, M.R.; Tomassini, B.; Ferrucci, P.F.; Ruthardt, M.; Gelmetti, V.; Gambacorti-Passerini, C.; Diverio, D.; et al. Caspases mediate retinoic acid-induced degradation of the acute promyelocytic leukemia PML/RARalpha fusion protein. Blood 1998, 92, 2244-2251. [PubMed]

23. Zhu, J.; Gianni, M.; Kopf, E.; Honore, N.; Chelbi-Alix, M.; Koken, M.; Quignon, F.; Rochette-Egly, C.; de The, H. Retinoic acid induces proteasome-dependent degradation of retinoic acid receptor alpha (RAR alpha) and oncogenic RAR alpha fusion proteins. Proc. Natl. Acad. Sci. USA 1999, 96, 14807-14812. [CrossRef] [PubMed]

24. Isakson, P.; Bjoras, M.; Boe, S.O.; Simonsen, A. Autophagy contributes to therapy-induced degradation of the PML/RARA oncoprotein. Blood 2010, 116, 2324-2331. [CrossRef] [PubMed]

25. Daniel, M.-T.; Koken, M.; Romagné, O.; Barbey, S.; Bazarbachi, A.; Stadler, M.; Guillemin, M.-C.; Degos, L.; Chomienne, C.; de Thé, H. PML protein expression in hematopoietic and acute promyelocytic leukemia cells. Blood 1993, 82, 1858-1867. [CrossRef] [PubMed]

26. Vitaliano-Prunier, A.; Halftermeyer, J.; Ablain, J.; de Reynies, A.; Peres, L.; Le Bras, M.; Metzger, D.; de The, H. Clearance of PML/RARA-bound promoters suffice to initiate APL differentiation. Blood 2014, 124, 3772-3780. [CrossRef] [PubMed]

27. Jeanne, M.; Lallemand-Breitenbach, V.; Ferhi, O.; Koken, M.; Le Bras, M.; Duffort, S.; Peres, L.; Berthier, C.; Soilihi, H.; Raught, B.; et al. PML/RARA oxidation and arsenic binding initiate the antileukemia response of $\mathrm{As}_{2} \mathrm{O}_{3}$. Cancer Cell 2010, 18, 88-98. [CrossRef]

28. Zhang, X.W.; Yan, X.J.; Zhou, Z.R.; Yang, F.F.; Wu, Z.Y.; Sun, H.B.; Liang, W.X.; Song, A.X.; Lallemand-Breitenbach, V.; Jeanne, M.; et al. Arsenic trioxide controls the fate of the PML-RARalpha oncoprotein by directly binding PML. Science 2010, 328, 240-243. [CrossRef]

29. Lallemand-Breitenbach, V.; Zhu, J.; Puvion, F.; Koken, M.; Honore, N.; Doubeikovsky, A.; Duprez, E.; Pandolfi, P.P.; Puvion, E.; Freemont, P.; et al. Role of Promyelocytic Leukemia (PML) Sumolation in Nuclear Body Formation, 11S Proteasome Recruitment, and $\mathrm{As}_{2} \mathrm{O}_{3}$-induced PML or PML/Retinoic Acid Receptor alpha Degradation. J. Exp. Med. 2001, 193, 1361-1372. [CrossRef]

30. Lallemand-Breitenbach, V.; Jeanne, M.; Benhenda, S.; Nasr, R.; Lei, M.; Peres, L.; Zhou, J.; Zhu, J.; Raught, B.; de The, H. Arsenic degrades PML or PML-RARalpha through a SUMO-triggered RNF4/ubiquitin-mediated pathway. Nat. Cell Biol. 2008, 10, 547-555. [CrossRef]

31. Tatham, M.H.; Geoffroy, M.C.; Shen, L.; Plechanovova, A.; Hattersley, N.; Jaffray, E.G.; Palvimo, J.J.; Hay, R.T. RNF4 is a poly-SUMO-specific E3 ubiquitin ligase required for arsenic-induced PML degradation. Nat. Cell Biol. 2008, 10, 538-546. [CrossRef] [PubMed]

32. Zhu, J.; Koken, M.H.M.; Quignon, F.; Chelbi-Alix, M.K.; Degos, L.; Wang, Z.Y.; Chen, Z.; de The, H. Arsenic-induced PML targeting onto nuclear bodies: Implications for the treatment of acute promyelocytic leukemia. Proc. Natl. Acad. Sci. USA 1997, 94, 3978-3983. [CrossRef] [PubMed]

33. Ablain, J.; Rice, K.; Soilihi, H.; de Reynies, A.; Minucci, S.; de The, H. Activation of a promyelocytic leukemia-tumor protein 53 axis underlies acute promyelocytic leukemia cure. Nat. Med. 2014, 20, 167-174. [CrossRef] [PubMed]

34. Nasr, R.; Guillemin, M.C.; Ferhi, O.; Soilihi, H.; Peres, L.; Berthier, C.; Rousselot, P.; Robledo-Sarmiento, M.; Lallemand-Breitenbach, V.; Gourmel, B.; et al. Eradication of acute promyelocytic leukemia-initiating cells through PML-RARA degradation. Nat. Med. 2008, 14, 1333-1342. [CrossRef]

35. Korf, K.; Wodrich, H.; Haschke, A.; Ocampo, C.; Harder, L.; Gieseke, F.; Pollmann, A.; Dierck, K.; Prall, S.; Staege, H.; et al. The PML domain of PML-RARalpha blocks senescence to promote leukemia. Proc. Natl. Acad. Sci. USA 2014, 111, 12133-12138. [CrossRef]

36. Lehmann-Che, J.; Bally, C.; de The, H. Therapy resistance in APL. N. Engl. J. Med. 2014, 371, 1171-1172.

37. Iaccarino, L.; Ottone, T.; Divona, M.; Cicconi, L.; Cairoli, R.; Voso, M.T.; Lo-Coco, F. Mutations affecting both the rearranged and the unrearranged PML alleles in refractory acute promyelocytic leukaemia. $\mathrm{Br}$. J. Haematol. 2016, 172, 909-913. [CrossRef] 
38. Mathews, V.; George, B.; Lakshmi, K.M.; Viswabandya, A.; Bajel, A.; Balasubramanian, P.; Shaji, R.V.; Srivastava, V.M.; Srivastava, A.; Chandy, M. Single-agent arsenic trioxide in the treatment of newly diagnosed acute promyelocytic leukemia: Durable remissions with minimal toxicity. Blood 2006, 107, 2627-2632. [CrossRef]

39. Madan, V.; Shyamsunder, P.; Han, L.; Mayakonda, A.; Nagata, Y.; Sundaresan, J.; Kanojia, D.; Yoshida, K.; Ganesan, S.; Hattori, N.; et al. Comprehensive mutational analysis of primary and relapse acute promyelocytic leukemia. Leukemia 2016, 30, 1672-1681. [CrossRef]

40. Lehmann-Che, J.; Bally, C.; Letouze, E.; Berthier, C.; Yuan, H.; Jollivet, F.; Ades, L.; Cassinat, B.; Hirsch, P.; Pigneux, A.; et al. Dual origin of relapses in retinoic-acid resistant acute promyelocytic leukemia. Nat. Commun. 2018, 9, 2047. [CrossRef]

41. Akagi, T.; Shih, L.Y.; Kato, M.; Kawamata, N.; Yamamoto, G.; Sanada, M.; Okamoto, R.; Miller, C.W.; Liang, D.C.; Ogawa, S.; et al. Hidden abnormalities and novel classification of $\mathrm{t}(15 ; 17)$ acute promyelocytic leukemia (APL) based on genomic alterations. Blood 2009, 113, 1741-1748. [CrossRef] [PubMed]

42. Welch, J.S.; Ley, T.J.; Link, D.C.; Miller, C.A.; Larson, D.E.; Koboldt, D.C.; Wartman, L.D.; Lamprecht, T.L.; Liu, F.; Xia, J.; et al. The origin and evolution of mutations in acute myeloid leukemia. Cell 2012, 150, $264-278$. [CrossRef] [PubMed]

43. Ibanez, M.; Carbonell-Caballero, J.; Garcia-Alonso, L.; Such, E.; Jimenez-Almazan, J.; Vidal, E.; Barragan, E.; Lopez-Pavia, M.; LLop, M.; Martin, I.; et al. The Mutational Landscape of Acute Promyelocytic Leukemia Reveals an Interacting Network of Co-Occurrences and Recurrent Mutations. PLoS ONE 2016, 11, e0148346. [CrossRef]

44. Zhao, J.; Liang, J.W.; Xue, H.L.; Shen, S.H.; Chen, J.; Tang, Y.J.; Yu, L.S.; Liang, H.H.; Gu, L.J.; Tang, J.Y.; et al. The genetics and clinical characteristics of children morphologically diagnosed as acute promyelocytic leukemia. Leukemia 2019, 33, 1387-1399. [CrossRef] [PubMed]

45. Iaccarino, L.; Ottone, T.; Alfonso, V.; Cicconi, L.; Divona, M.; Lavorgna, S.; Travaglini, S.; Ferrantini, A.; Falconi, G.; Baer, C.; et al. Mutational landscape of patients with acute promyelocytic leukemia at diagnosis and relapse. Am. J. Hematol. 2019, 94, 1091-1097. [CrossRef] [PubMed]

46. Gallagher, R.E. Retinoic acid resistance in acute promyelocytic leukemia. Leuk. Off. J. Leuk. Soc. Am. Leuk. Res. Fund UK 2002, 16, 1940-1958. [CrossRef]

47. Gallagher, R.E.; Moser, B.K.; Racevskis, J.; Poire, X.; Bloomfield, C.D.; Carroll, A.J.; Ketterling, R.P.; Roulston, D.; Schachter-Tokarz, E.; Zhou, D.C.; et al. Treatment-influenced associations of PML-RARalpha mutations, FLT3 mutations, and additional chromosome abnormalities in relapsed acute promyelocytic leukemia. Blood 2012, 120, 2098-2108. [CrossRef]

48. Zhu, H.H.; Qin, Y.Z.; Huang, X.J. Resistance to arsenic therapy in acute promyelocytic leukemia. N. Engl. J. Med. 2014, 370, 1864-1866. [CrossRef]

49. Lou, Y.; Ma, Y.; Sun, J.; Ye, X.; Pan, H.; Wang, Y.; Qian, W.; Meng, H.; Mai, W.; He, J.; et al. Evaluating frequency of PML-RARA mutations and conferring resistance to arsenic trioxide-based therapy in relapsed acute promyelocytic leukemia patients. Ann. Hematol. 2015, 94, 1829-1837. [CrossRef]

50. Shen, Y.; Fu, Y.K.; Zhu, Y.M.; Lou, Y.J.; Gu, Z.H.; Shi, J.Y.; Chen, B.; Chen, C.; Zhu, H.H.; Hu, J.; et al. Mutations of Epigenetic Modifier Genes as a Poor Prognostic Factor in Acute Promyelocytic Leukemia Under Treatment With All-Trans Retinoic Acid and Arsenic Trioxide. EBioMedicine 2015, 2, 563-571. [CrossRef]

51. Lucena-Araujo, A.R.; Coelho-Silva, J.L.; Pereira-Martins, D.A.; Silveira, D.R.; Koury, L.C.; Melo, R.A.M.; Bittencourt, R.; Pagnano, K.; Pasquini, R.; Nunes, E.C.; et al. Combining gene mutation with gene expression analysis improves outcome prediction in acute promyelocytic leukemia. Blood 2019, 134, 951-959. [CrossRef] [PubMed]

52. Fan, Y.; Cao, Y.; Bai, X.; Zhuang, W. The clinical significance of FLT3 ITD mutation on the prognosis of adult acute promyelocytic leukemia. Hematology 2018, 23, 379-384. [CrossRef]

53. Picharski, G.L.; Andrade, D.P.; Fabro, A.; Lenzi, L.; Tonin, F.S.; Ribeiro, R.C.; Figueiredo, B.C. The Impact of Flt3 Gene Mutations in Acute Promyelocytic Leukemia: A Meta-Analysis. Cancers 2019, 11, 1311. [CrossRef] [PubMed]

54. Esnault, C.; Rahme, R.; Rice, K.L.; Berthier, C.; Gaillard, C.; Quentin, S.; Maubert, A.L.; Kogan, S.; de The, H. FLT3-ITD impedes retinoic acid, but not arsenic, responses in murine acute promyelocytic leukemias. Blood 2019, 133, 1495-1506. [CrossRef] 
55. Cicconi, L.; Divona, M.; Ciardi, C.; Ottone, T.; Ferrantini, A.; Lavorgna, S.; Alfonso, V.; Paoloni, F.; Piciocchi, A.; Avvisati, G.; et al. PML-RARalpha kinetics and impact of FLT3-ITD mutations in newly diagnosed acute promyelocytic leukaemia treated with ATRA and ATO or ATRA and chemotherapy. Leukemia 2016, 30, 1987-1992. [CrossRef]

56. Poire, X.; Moser, B.K.; Gallagher, R.E.; Laumann, K.; Bloomfield, C.D.; Powell, B.L.; Koval, G.; Gulati, K.; Holowka, N.; Larson, R.A.; et al. Arsenic trioxide in front-line therapy of acute promyelocytic leukemia (C9710): Prognostic significance of FLT3 mutations and complex karyotype. Leuk. Lymphoma 2014, 55, 1523-1532. [CrossRef] [PubMed]

57. Yan, W.; Zhang, G. Molecular Characteristics and Clinical Significance of 12 Fusion Genes in Acute Promyelocytic Leukemia: A Systematic Review. Acta Haematol. 2016, 136, 1-15. [CrossRef] [PubMed]

58. Baba, S.M.; Pandith, A.A.; Shah, Z.A.; Baba, R.A. Pathogenetic implication of fusion genes in acute promyelocytic leukemia and their diagnostic utility. Clin. Genet. 2019, 95, 41-52. [CrossRef]

59. Liquori, A.; Ibanez, M.; Sargas, C.; Sanz, M.A.; Barragan, E.; Cervera, J. Acute Promyelocytic Leukemia: A Constellation of Molecular Events around a Single PML-RARA Fusion Gene. Cancers 2020, 12, 624. [CrossRef]

60. Conserva, M.R.; Redavid, I.; Anelli, L.; Zagaria, A.; Specchia, G.; Albano, F. RARG Gene Dysregulation in Acute Myeloid Leukemia. Front. Mol. Biosci. 2019, 6, 114. [CrossRef]

61. Chen, Z.; Brand, N.; Chen, A.; Chen, S.; Tong, J.; Wang, Z.; Waxman, S.; Zelent, A. Fusion between a novel Kruppel-like zinc finger gene and the retinoic acid receptor a locus due to a variant $t(11,17)$ translocation in acute promyelocytic leukemia. EMBO J. 1993, 12, 1161-1167. [CrossRef] [PubMed]

62. Yamamoto, Y.; Tsuzuki, S.; Tsuzuki, M.; Handa, K.; Inaguma, Y.; Emi, N. BCOR as a novel fusion partner of retinoic acid receptor alpha in a $\mathrm{t}(\mathrm{X} ; 17)(\mathrm{p} 11 ; \mathrm{q} 12)$ variant of acute promyelocytic leukemia. Blood 2010, 116, 4274-4283. [CrossRef] [PubMed]

63. Kondo, T.; Mori, A.; Darmanin, S.; Hashino, S.; Tanaka, J.; Asaka, M. The seventh pathogenic fusion gene FIP1L1-RARA was isolated from a t(4;17)-positive acute promyelocytic leukemia. Haematologica 2008, 93, 1414-1416. [CrossRef] [PubMed]

64. Menezes, J.; Acquadro, F.; Perez-Pons de la Villa, C.; Garcia-Sanchez, F.; Alvarez, S.; Cigudosa, J.C. FIP1L1/RARA with breakpoint at FIP1L1 intron 13: A variant translocation in acute promyelocytic leukemia. Haematologica 2011, 96, 1565-1566. [CrossRef]

65. Cheng, C.K.; Wang, A.Z.; Wong, T.H.Y.; Wan, T.S.K.; Cheung, J.S.; Raghupathy, R.; Chan, N.P.H.; Ng, M.H.L. FNDC3B is another novel partner fused to RARA in the $t(3 ; 17)(q 26 ; q 21)$ variant of acute promyelocytic leukemia. Blood 2017, 129, 2705-2709. [CrossRef]

66. Li, J.; Zhong, H.Y.; Zhang, Y.; Xiao, L.; Bai, L.H.; Liu, S.F.; Zhou, G.B.; Zhang, G.S. GTF2I-RARA is a novel fusion transcript in a $t(7 ; 17)$ variant of acute promyelocytic leukaemia with clinical resistance to retinoic acid. Br. J. Haematol. 2015, 168, 904-908. [CrossRef]

67. Jovanovic, J.V.; Chillon, M.C.; Vincent-Fabert, C.; Dillon, R.; Voisset, E.; Gutierrez, N.C.; Sanz, R.G.; Lopez, A.A.; Morgan, Y.G.; Lok, J.; et al. The cryptic IRF2BP2-RARA fusion transforms hematopoietic stem/progenitor cells and induces retinoid-sensitive acute promyelocytic leukemia. Leukemia 2017, 31, 747-751. [CrossRef]

68. Shimomura, Y.; Mitsui, H.; Yamashita, Y.; Kamae, T.; Kanai, A.; Matsui, H.; Ishibashi, T.; Tanimura, A.; Shibayama, H.; Oritani, K.; et al. New variant of acute promyelocytic leukemia with IRF2BP2-RARA fusion. Cancer Sci. 2016, 107, 1165-1168. [CrossRef] [PubMed]

69. Mazharuddin, S.; Chattopadhyay, A.; Levy, M.Y.; Redner, R.L. IRF2BP2-RARA t(1;17)(q42.3;q21.2) APL blasts differentiate in response to all-trans retinoic acid. Leuk. Lymphoma 2018, 59, 2246-2249. [CrossRef]

70. Liu, Y.; Xu, F.; Hu, H.; Wen, J.; Su, J.; Zhou, Q.; Qu, W. A rare case of acute promyelocytic leukemia with IRF2BP2-RARA fusion; and literature review. OncoTargets Ther. 2019, 12, 6157-6163. [CrossRef]

71. Yin, C.C.; Jain, N.; Mehrotra, M.; Zhagn, J.; Protopopov, A.; Zuo, Z.; Pemmaraju, N.; DiNardo, C.; Hirsch-Ginsberg, C.; Wang, S.A.; et al. Identification of a novel fusion gene, IRF2BP2-RARA, in acute promyelocytic leukemia. J. Natl. Compr. Cancer Netw. 2015, 13, 19-22. [CrossRef] [PubMed]

72. Won, D.; Shin, S.Y.; Park, C.J.; Jang, S.; Chi, H.S.; Lee, K.H.; Lee, J.O.; Seo, E.J. OBFC2A/RARA: A novel fusion gene in variant acute promyelocytic leukemia. Blood 2013, 121, 1432-1435. [CrossRef] [PubMed]

73. Redner, R.L.; Rush, E.A.; Faas, S.; Rudert, W.A.; Corey, S.J. The t(5-17) variant of acute promyelocytic leukemia expresses a nucleophosmin retinoic acid receptor fusion. Blood 1996, 87, 882-886. [CrossRef] [PubMed] 
74. Wells, R.A.; Catzavelos, C.; Kamel-Reid, S. Fusion of retinoic acid receptor alpha to NuMA, the nuclear mitotic apparatus protein, by a variant translocation in acute promyelocytic leukaemia. Nat. Genet. 1997, 17, 109-113. [CrossRef] [PubMed]

75. Wells, R.A.; Hummel, J.L.; De Koven, A.; Zipursky, A.; Kirby, M.; Dube, I.; Kamel-Reid, S. A new variant translocation in acute promyelocytic leukaemia: Molecular characterization and clinical correlation. Leukemia 1996, 10, 735-740. [PubMed]

76. Catalano, A.; Dawson, M.A.; Somana, K.; Opat, S.; Schwarer, A.; Campbell, L.J.; Iland, H. The PRKAR1A gene is fused to RARA in a new variant acute promyelocytic leukemia. Blood 2007, 110, 4073-4076. [CrossRef] [PubMed]

77. Yao, L.; Wen, L.; Wang, N.; Liu, T.; Xu, Y.; Ruan, C.; Wu, D.; Chen, S. Identification of novel recurrent STAT3-RARA fusions in acute promyelocytic leukemia lacking t(15;17)(q22;q12)/PML-RARA. Blood 2018, 131, 935-939. [CrossRef]

78. Arnould, C.; Philippe, C.; Bourdon, V.; Gregoire, M.J.; Berger, R.; Jonveaux, P. The signal transducer and activator of transcription STAT5b gene is a new partner of retinoic acid receptor alpha in acute promyelocytic-like leukaemia. Hum. Mol. Genet. 1999, 8, 1741-1749. [CrossRef]

79. Chen, Y.; Li, S.; Zhou, C.; Li, C.; Ru, K.; Rao, Q.; Xing, H.; Tian, Z.; Tang, K.; Mi, Y.; et al. TBLR1 fuses to retinoid acid receptor alpha in a variant $\mathrm{t}(3 ; 17)(\mathrm{q} 26 ; \mathrm{q} 21)$ translocation of acute promyelocytic leukemia. Blood 2014, 124, 936-945. [CrossRef]

80. Osumi, T.; Watanabe, A.; Okamura, K.; Nakabayashi, K.; Yoshida, M.; Tsujimoto, S.I.; Uchiyama, M.; Takahashi, H.; Tomizawa, D.; Hata, K.; et al. Acute promyelocytic leukemia with a cryptic insertion of RARA into TBL1XR1. Genes Chromosom. Cancer 2019, 58, 820-823. [CrossRef]

81. Chong, M.L.; Cheng, H.; Xu, P.; You, H.; Wang, M.; Wang, L.; Ho, H.H. TFG-RARA: A novel fusion gene in acute promyelocytic leukemia that is responsive to all-trans retinoic acid. Leuk. Res. 2018, 74, 51-54. [CrossRef] [PubMed]

82. Osumi, T.; Tsujimoto, S.I.; Tamura, M.; Uchiyama, M.; Nakabayashi, K.; Okamura, K.; Yoshida, M.; Tomizawa, D.; Watanabe, A.; Takahashi, H.; et al. Recurrent RARB Translocations in Acute Promyelocytic Leukemia Lacking RARA Translocation. Cancer Res. 2018, 78, 4452-4458. [CrossRef] [PubMed]

83. Liu, T.; Wen, L.; Yuan, H.; Wang, Y.; Yao, L.; Xu, Y.; Cen, J.; Ruan, C.; Wu, D.; Chen, S. Identification of novel recurrent CPSF6-RARG fusions in acute myeloid leukemia resembling acute promyelocytic leukemia. Blood 2018, 131, 1870-1873. [CrossRef] [PubMed]

84. Qin, Y.Z.; Huang, X.J.; Zhu, H.H. Identification of a novel CPSF6-RARG fusion transcript in acute myeloid leukemia resembling acute promyelocytic leukemia. Leukemia 2018, 32, 2285-2287. [CrossRef] [PubMed]

85. Zhang, Z.; Jiang, M.; Borthakur, G.; Luan, S.; Huang, X.; Tang, G.; Xu, Q.; Ji, D.; Boyer, A.D.; Li, F.; et al. Acute myeloid leukemia with a novel CPSF6-RARG variant is sensitive to homoharringtonine and cytarabine chemotherapy. Am. J. Hematol. 2020, 95, E48-E51. [CrossRef]

86. Chen, X.; Wang, F.; Zhang, Y.; Teng, W.; Cao, P.; Ma, X.; Liu, M.; Tian, Y.; Wang, T.; Nie, D.; et al. A novel NPM1-RARG-NPM1 chimeric fusion in acute myeloid leukaemia resembling acute promyelocytic leukaemia but resistant to all-trans retinoic acid and arsenic trioxide. Br. J. Cancer 2019, 120, 1023-1025. [CrossRef]

87. Such, E.; Cervera, J.; Valencia, A.; Barragan, E.; Ibanez, M.; Luna, I.; Fuster, O.; Perez-Sirvent, M.L.; Senent, L.; Sempere, A.; et al. A novel NUP98/RARG gene fusion in acute myeloid leukemia resembling acute promyelocytic leukemia. Blood 2011, 117, 242-245. [CrossRef] [PubMed]

88. Luo, H.; Zhang, S.; Li, K.; Chen, X.H.; Li, Y.C.; Sun, Y.; Liu, L.F.; Yu, H.Y.; Zhu, H.H. A novel entity of acute myeloid leukaemia with recurrent RARG-rearrangement resembling acute promyelocytic leukaemia. Leuk. Res. 2019, 77, 14-16. [CrossRef]

89. Zhang, X.; Li, F.; Wang, J.; Suo, S.; Ling, Q.; Yu, W.; Jin, J. RARgamma-rearrangements resemble acute promyelocytic leukemia and benefit from $3+7$ regimen. Leuk. Lymphoma 2019, 60, 1831-1834. [CrossRef]

90. Ha, J.S.; Do, Y.R.; Ki, C.S.; Lee, C.; Kim, D.H.; Lee, W.; Ryoo, N.H.; Jeon, D.S. Identification of a novel PML-RARG fusion in acute promyelocytic leukemia. Leukemia 2017, 31, 1992-1995. [CrossRef]

91. Licht, J.D. Reconstructing a disease: What essential features of the retinoic acid receptor fusion oncoproteins generate acute promyelocytic leukemia? Cancer Cell 2006, 9, 73-74. [CrossRef]

92. Kamashev, D.E.; Vitoux, D.; De Thé, H. PML/RARA-RXR oligomers mediate retinoid- and rexinoid-/cAMP in APL cell differentiation. J. Exp. Med. 2004, 199, 1-13. [CrossRef] [PubMed] 
93. Martens, J.H.; Brinkman, A.B.; Simmer, F.; Francoijs, K.J.; Nebbioso, A.; Ferrara, F.; Altucci, L.; Stunnenberg, H.G. PML-RARalpha/RXR Alters the Epigenetic Landscape in Acute Promyelocytic Leukemia. Cancer Cell 2010, 17, 173-185. [CrossRef]

94. Zhu, J.; Nasr, R.; Peres, L.; Riaucoux-Lormiere, F.; Honore, N.; Berthier, C.; Kamashev, D.; Zhou, J.; Vitoux, D.; Lavau, C.; et al. RXR is an essential component of the oncogenic PML/RARA complex in vivo. Cancer Cell 2007, 12, 23-35. [CrossRef] [PubMed]

95. Tsai, S.; Bartelmez, S.; Heyman, R.; Damm, K.; Evans, R.; Collins, S.J. A mutated retinoic acid receptor a exhibiting dominant- negative activity alters the lineage development of a multipotent hematopoietic cell line. Genes Dev. 1993, 6, 2258-2269. [CrossRef] [PubMed]

96. Vickers, M.; Jackson, G.; Taylor, P. The incidence of acute promyelocytic leukemia appears constant over most of a human lifespan, implying only one rate limiting mutation. Leukemia 2000, 14, 722-726. [CrossRef]

97. Suliman, B.A.; Xu, D.; Williams, B.R. The promyelocytic leukemia zinc finger protein: Two decades of molecular oncology. Front. Oncol. 2012, 2, 74. [CrossRef]

98. He, L.; Bhaumik, M.; Tribioli, C.; Rego, E.M.; Ivins, S.; Zelent, A.; Pandolfi, P.P. Two critical hits for promyelocytic leukemia. Mol. Cell 2000, 6, 1131-1141. [CrossRef]

99. Guidez, F.; Parks, S.; Wong, H.; Jovanovic, J.V.; Mays, A.; Gilkes, A.F.; Mills, K.I.; Guillemin, M.C.; Hobbs, R.M.; Pandolfi, P.P.; et al. RARalpha-PLZF overcomes PLZF-mediated repression of CRABPI, contributing to retinoid resistance in $\mathrm{t}(11 ; 17)$ acute promyelocytic leukemia. Proc. Natl. Acad. Sci. USA 2007, 104, 18694-18699. [CrossRef]

100. Licht, J.D.; Chomienne, C.; Goy, A.; Chen, A.; Scott, A.A.; Head, D.R.; Michaux, J.L.; Wu, Y.; DeBlasio, A.; Miller, W.H., Jr.; et al. Clinical and molecular characterization of a rare syndrome of acute promyelocytic leukemia associated with translocation (11;17). Blood 1995, 85, 1083-1094. [CrossRef]

101. Koken, M.H.M.; Daniel, M.-T.; Gianni, M.; Zelent, A.; Licht, J.; Buzyn, A.; Minard, P.; Degos, L.; Varet, B.; de The, H. Retinoic acid, but not arsenic trioxide, degrades the PLZF/RARalpha fusion protein, without inducing terminal differentiation or apoptosis, in a RA-therapy resistant $\operatorname{tt}(11 ; 17)(\mathrm{q} 23 ; \mathrm{q} 21)$ APL patient. Oncogene 1999, 18, 1113-1118. [CrossRef] [PubMed]

102. Rego, E.M.; He, L.Z.; Warrell, R.P., Jr.; Wang, Z.G.; Pandolfi, P.P. Retinoic acid (RA) and As2O3 treatment in transgenic models of acute promyelocytic leukemia (APL) unravel the distinct nature of the leukemogenic process induced by the PML-RARalpha and PLZF-RARalpha oncoproteins. Proc. Natl. Acad. Sci. USA 2000, 97, 10173-10178. [CrossRef] [PubMed]

103. He, L.Z.; Tolentino, T.; Grayson, P.; Zhong, S.; Warrell, R.P., Jr.; Rifkind, R.A.; Marks, P.A.; Richon, V.M.; Pandolfi, P.P. Histone deacetylase inhibitors induce remission in transgenic models of therapy-resistant acute promyelocytic leukemia. J. Clin. Investig. 2001, 108, 1321-1330. [CrossRef] [PubMed]

104. Petti, M.C.; Fazi, F.; Gentile, M.; Diverio, D.; De Fabritiis, P.; De Propris, M.S.; Fiorini, R.; Spiriti, M.A.; Padula, F.; Pelicci, P.G.; et al. Complete remission through blast cell differentiation in PLZF/RARalpha-positive acute promyelocytic leukemia: In vitro and in vivo studies. Blood 2002, 100, 1065-1067. [CrossRef] [PubMed]

105. Jansen, J.H.; Lowenberg, B. Acute promyelocytic leukemia with a PLZF-RARalpha fusion protein. Semin. Hematol. 2001, 38, 37-41. [CrossRef]

106. Kitamura, K.; Hoshi, S.; Koike, M.; Kiyoi, H.; Saito, H.; Naoe, T. Histone deacetylase inhibitor but not arsenic trioxide differentiates acute promyelocytic leukaemia cells with $\mathrm{t}(11 ; 17)$ in combination with all-trans retinoic acid. Br. J. Haematol. 2000, 108, 696-702. [CrossRef]

107. Astolfi, A.; Fiore, M.; Melchionda, F.; Indio, V.; Bertuccio, S.N.; Pession, A. BCOR involvement in cancer. Epigenomics 2019, 11, 835-855. [CrossRef]

108. Cardenas, M.G.; Oswald, E.; Yu, W.; Xue, F.; MacKerell, A.D., Jr.; Melnick, A.M. The Expanding Role of the BCL6 Oncoprotein as a Cancer Therapeutic Target. Clin. Cancer Res. 2017, 23, 885-893. [CrossRef]

109. Ichikawa, S.; Ichikawa, S.; Ishikawa, I.; Takahashi, T.; Fujiwara, T.; Harigae, H. Successful treatment of acute promyelocytic leukemia with a $\mathrm{t}(\mathrm{X} ; 17)(\mathrm{p} 11.4 ; \mathrm{q} 21)$ and BCOR-RARA fusion gene. Cancer Genet. 2015, 208, 162-163. [CrossRef]

110. Cools, J.; DeAngelo, D.J.; Gotlib, J.; Stover, E.H.; Legare, R.D.; Cortes, J.; Kutok, J.; Clark, J.; Galinsky, I.; Griffin, J.D.; et al. A tyrosine kinase created by fusion of the PDGFRA and FIP1L1 genes as a therapeutic target of imatinib in idiopathic hypereosinophilic syndrome. N. Engl. J. Med. 2003, 348, 1201-1214. [CrossRef] 
111. Iwasaki, J.; Kondo, T.; Darmanin, S.; Ibata, M.; Onozawa, M.; Hashimoto, D.; Sakamoto, N.; Teshima, T. FIP1L1 presence in FIP1L1-RARA or FIP1L1-PDGFRA differentially contributes to the pathogenesis of distinct types of leukemia. Ann. Hematol. 2014, 93, 1473-1481. [CrossRef]

112. Tominaga, K.; Kondo, C.; Johmura, Y.; Nishizuka, M.; Imagawa, M. The novel gene fad104, containing a fibronectin type III domain, has a significant role in adipogenesis. FEBS Lett. 2004, 577, 49-54. [CrossRef]

113. Lin, C.H.; Lin, Y.W.; Chen, Y.C.; Liao, C.C.; Jou, Y.S.; Hsu, M.T.; Chen, C.F. FNDC3B promotes cell migration and tumor metastasis in hepatocellular carcinoma. Oncotarget 2016, 7, 49498-49508. [CrossRef]

114. Roy, A.L. Pathophysiology of TFII-I: Old Guard Wearing New Hats. Trends Mol. Med. 2017, 23, 501-511. [CrossRef]

115. Yan, W.; Li, J.; Zhang, Y.; Yin, Y.; Cheng, Z.; Wang, J.; Hu, G.; Liu, S.; Wang, Y.; Xu, Y.; et al. RNF8 is responsible for ATRA resistance in variant acute promyelocytic leukemia with GTF2I/RARA fusion, and inhibition of the ubiquitin-proteasome pathway contributes to the reversion of ATRA resistance. Cancer Cell Int. 2019, $19,84$. [CrossRef]

116. Ramalho-Oliveira, R.; Oliveira-Vieira, B.; Viola, J.P.B. IRF2BP2: A new player in the regulation of cell homeostasis. J. Leukoc. Biol. 2019, 106, 717-723. [CrossRef]

117. Ashton, N.W.; Bolderson, E.; Cubeddu, L.; O’Byrne, K.J.; Richard, D.J. Human single-stranded DNA binding proteins are essential for maintaining genomic stability. BMC Mol. Biol. 2013, 14, 9. [CrossRef] [PubMed]

118. Box, J.K.; Paquet, N.; Adams, M.N.; Boucher, D.; Bolderson, E.; O’Byrne, K.J.; Richard, D.J. Nucleophosmin: From structure and function to disease development. BMC Mol. Biol. 2016, 17, 19. [CrossRef] [PubMed]

119. Falini, B.; Mecucci, C.; Tiacci, E.; Alcalay, M.; Rosati, R.; Pasqualucci, L.; La Starza, R.; Diverio, D.; Colombo, E.; Santucci, A.; et al. Cytoplasmic nucleophosmin in acute myelogenous leukemia with a normal karyotype. $N$. Engl. J. Med. 2005, 352, 254-266. [CrossRef] [PubMed]

120. Pollock, S.L.; Rush, E.A.; Redner, R.L. NPM-RAR, not the RAR-NPM reciprocal t(5;17)(q35;q21) acute promyelocytic leukemia fusion protein, inhibits myeloid differentiation. Leuk. Lymphoma 2014, 55, 1383-1387. [CrossRef] [PubMed]

121. Sportoletti, P.; Grisendi, S.; Majid, S.M.; Cheng, K.; Clohessy, J.G.; Viale, A.; Teruya-Feldstein, J.; Pandolfi, P.P. Npm1 is a haploinsufficient suppressor of myeloid and lymphoid malignancies in the mouse. Blood 2008, 111, 3859-3862. [CrossRef] [PubMed]

122. Hummel, J.L.; Wells, R.A.; Dube, I.D.; Licht, J.D.; Kamel-Reid, S. Deregulation of NPM and PLZF in a variant $\mathrm{t}(5 ; 17)$ case of acute promyelocytic leukemia. Oncogene 1999, 18, 633-641. [CrossRef] [PubMed]

123. Xu, L.; Zhao, W.L.; Xiong, S.M.; Su, X.Y.; Zhao, M.; Wang, C.; Gao, Y.R.; Niu, C.; Cao, Q.; Gu, B.W.; et al. Molecular cytogenetic characterization and clinical relevance of additional, complex and/or variant chromosome abnormalities in acute promyelocytic leukemia. Leukemia 2001, 15, 1359-1368. [CrossRef] [PubMed]

124. Nicci, C.; Ottaviani, E.; Luatti, S.; Grafone, T.; Tonelli, M.; Motta, M.R.; Malagola, M.; Marzocchi, G.; Martinelli, G.; Baccarani, M.; et al. Molecular and cytogenetic characterization of a new case of t(5;17)(q35;q21) variant acute promyelocytic leukemia. Leukemia 2005, 19, 470-472. [CrossRef] [PubMed]

125. Kikuma, T.; Nakamachi, Y.; Noguchi, Y.; Okazaki, Y.; Shimomura, D.; Yakushijin, K.; Yamamoto, K.; Matsuoka, H.; Minami, H.; Itoh, T.; et al. A new transcriptional variant and small azurophilic granules in an acute promyelocytic leukemia case with NPM1/RARA fusion gene. Int. J. Hematol. 2015, 102, 713-718. [CrossRef] [PubMed]

126. Okazuka, K.; Masuko, M.; Seki, Y.; Hama, H.; Honma, N.; Furukawa, T.; Toba, K.; Kishi, K.; Aizawa, Y. Successful all-trans retinoic acid treatment of acute promyelocytic leukemia in a patient with NPM/RAR fusion. Int. J. Hematol. 2007, 86, 246-249. [CrossRef]

127. Yanagisawa, R.; Ogiso, Y.; Yoshikawa, K.; Tanaka, M.; Matsuda, K.; Ishii, E. Myelomonocytic differentiation associated with NPM1-RARA rearrangement. Br. J. Haematol. 2017, 179, 183. [CrossRef]

128. Di Pietro, F.; Echard, A.; Morin, X. Regulation of mitotic spindle orientation: An integrated view. EMBO Rep. 2016, 17, 1106-1130. [CrossRef]

129. Kamilaris, C.D.C.; Faucz, F.R.; Voutetakis, A.; Stratakis, C.A. Carney Complex. Exp. Clin. Endocrinol. Diabetes 2019, 127, 156-164. [CrossRef]

130. Zeisig, B.B.; Kwok, C.; Zelent, A.; Shankaranarayanan, P.; Gronemeyer, H.; Dong, S.; So, C.W. Recruitment of RXR by homotetrameric RARalpha fusion proteins is essential for transformation. Cancer Cell 2007, 12, 36-51. [CrossRef] 
131. Qiu, J.J.; Lu, X.; Zeisig, B.B.; Ma, Z.; Cai, X.; Chen, S.; Gronemeyer, H.; Tweardy, D.J.; So, C.W.; Dong, S. Leukemic transformation by the APL fusion protein PRKAR1A-RAR \{alpha\} critically depends on recruitment of RXR\{alpha\}. Blood 2010, 115, 643-652. [CrossRef] [PubMed]

132. Orlova, A.; Wagner, C.; de Araujo, E.D.; Bajusz, D.; Neubauer, H.A.; Herling, M.; Gunning, P.T.; Keseru, G.M.; Moriggl, R. Direct Targeting Options for STAT3 and STAT5 in Cancer. Cancers 2019, 11, 1390. [CrossRef] [PubMed]

133. Kusakabe, M.; Suzukawa, K.; Nanmoku, T.; Obara, N.; Okoshi, Y.; Mukai, H.Y.; Hasegawa, Y.; Kojima, H.; Kawakami, Y.; Ninomiya, H.; et al. Detection of the STAT5B-RARA fusion transcript in acute promyelocytic leukemia with the normal chromosome 17 on G-banding. Eur. J. Haematol. 2008, 80, 444-447. [CrossRef] [PubMed]

134. Iwanaga, E.; Nakamura, M.; Nanri, T.; Kawakita, T.; Horikawa, K.; Mitsuya, H.; Asou, N. Acute promyelocytic leukemia harboring a STAT5B-RARA fusion gene and a G596V missense mutation in the STAT5B SH2 domain of the STAT5B-RARA. Eur. J. Haematol. 2009, 83, 499-501. [CrossRef] [PubMed]

135. Strehl, S.; Konig, M.; Boztug, H.; Cooper, B.W.; Suzukawa, K.; Zhang, S.J.; Chen, H.Y.; Attarbaschi, A.; Dworzak, M.N. All-trans retinoic acid and arsenic trioxide resistance of acute promyelocytic leukemia with the variant STAT5B-RARA fusion gene. Leukemia 2013, 27, 1606-1610. [CrossRef] [PubMed]

136. Wang, Y.Y.; Hao, J.; Liu, Z.Y.; Weng, X.Q.; Sheng, Y.; Jiang, C.L.; Zhu, Y.M.; Chen, B.; Xiong, S.M.; Li, J.M.; et al. Novel STAT5B-RARA fusion transcript in acute promyelocytic leukemia: Identification and treatment response. Leuk. Lymphoma 2015, 56, 2731-2734. [CrossRef] [PubMed]

137. Kluk, M.J.; Abo, R.P.; Brown, R.D.; Kuo, F.C.; Dal Cin, P.; Pozdnyakova, O.; Morgan, E.A.; Lindeman, N.I.; DeAngelo, D.J.; Aster, J.C. Myeloid neoplasm demonstrating a STAT5B-RARA rearrangement and genetic alterations associated with all-trans retinoic acid resistance identified by a custom next-generation sequencing assay. Cold Spring Harb. Mol. Case Stud. 2015, 1, a000307. [CrossRef]

138. Ciangola, G.; Gurnari, C.; Paterno, G.; Mirabile, M.; Angelini, M.; Lavorgna, S.; Ottone, T.; Travaglini, S.; Cicconi, L.; LoCoco, F. STAT5b-RARa-positive acute myeloid leukemia: Diagnostic and therapeutic challenges of a rare AML subtype. Leuk. Res. 2019, 78, 21-23. [CrossRef]

139. Wang, A.; Cai, X.; Qiang, P.; Duan, Q. Successful treatment of a patient with acute promyelocytic leukemia with a STAT5B/RARA fusion gene using decitabine. Leuk. Lymphoma 2018, 59, 763-765. [CrossRef]

140. Liang, N.; Jakobsson, T.; Fan, R.; Treuter, E. The Nuclear Receptor-Co-repressor Complex in Control of Liver Metabolism and Disease. Front. Endocrinol. 2019, 10, 411. [CrossRef]

141. Chen, Y.; Tseng, S.H. Targeting tropomyosin-receptor kinase fused gene in cancer. Anticancer Res. 2014, 34, 1595-1600. [PubMed]

142. Hernandez, L.; Bea, S.; Bellosillo, B.; Pinyol, M.; Falini, B.; Carbone, A.; Ott, G.; Rosenwald, A.; Fernandez, A.; Pulford, K.; et al. Diversity of genomic breakpoints in TFG-ALK translocations in anaplastic large cell lymphomas: Identification of a new TFG-ALK $(\mathrm{XL})$ chimeric gene with transforming activity. Am. J. Pathol. 2002, 160, 1487-1494. [CrossRef]

143. Kastner, P.; Mark, M.; Chambon, P. Nonsteroid nuclear receptors: What are genetic studies telling us about their role in real life? Cell 1995, 83, 859-869. [CrossRef]

144. Samarut, E.; Rochette-Egly, C. Nuclear retinoic acid receptors: Conductors of the retinoic acid symphony during development. Mol. Cell. Endocrinol. 2012, 348, 348-360. [CrossRef]

145. Duong, V.; Rochette-Egly, C. The molecular physiology of nuclear retinoic acid receptors. From health to disease. Biochim. Biophys. Acta 2011, 1812, 1023-1031. [CrossRef] [PubMed]

146. Marinelli, A.; Bossi, D.; Pelicci, P.G.; Minucci, S. A redundant oncogenic potential of the retinoic receptor (RAR) alpha, beta and gamma isoforms in acute promyelocytic leukemia. Leukemia 2007, 21, 647-650. [CrossRef]

147. Miller, C.A.; Tricarico, C.; Skidmore, Z.L.; Uy, G.L.; Lee, Y.S.; Hassan, A.; O’Laughlin, M.D.; Schmidt, H.; Tian, L.; Duncavage, E.J.; et al. A case of acute myeloid leukemia with promyelocytic features characterized by expression of a novel RARG-CPSF6 fusion. Blood Adv. 2018, 2, 1295-1299. [CrossRef]

148. Takeda, A.; Yaseen, N.R. Nucleoporins and nucleocytoplasmic transport in hematologic malignancies. Semin. Cancer Biol. 2014, 27, 3-10. [CrossRef] [PubMed]

149. Qiu, J.J.; Zeisig, B.B.; Li, S.; Liu, W.; Chu, H.; Song, Y.; Giordano, A.; Schwaller, J.; Gronemeyer, H.; Dong, S.; et al. Critical role of retinoid/rexinoid signaling in mediating transformation and therapeutic response of NUP98-RARG leukemia. Leukemia 2015, 29, 1153-1162. [CrossRef] [PubMed] 
150. McKenzie, M.D.; Ghisi, M.; Oxley, E.P.; Ngo, S.; Cimmino, L.; Esnault, C.; Liu, R.; Salmon, J.M.; Bell, C.C.; Ahmed, N.; et al. Interconversion between Tumorigenic and Differentiated States in Acute Myeloid Leukemia. Cell Stem Cell 2019, 25, 258-272. [CrossRef] [PubMed]

151. Muller, S.; Matunis, M.J.; Dejean, A. Conjugation with the ubiquitin-related modifier SUMO-1 regulates the partitioning of PML within the nucleus. EMBO J. 1998, 17, 61-70. [CrossRef] [PubMed]

152. Chen, G.Q.; Shi, X.G.; Tang, W.; Xiong, S.M.; Zhu, J.; Cai, X.; Han, Z.G.; Ni, J.H.; Shi, G.Y.; Jia, P.M.; et al. Use of arsenic trioxide (As2O3) in the treatment of acute promyelocytic leukemia (APL): I. As2O3 exerts dose-dependent dual effects on APL cells. Blood 1997, 89, 3345-3353. [PubMed]

153. Wong, C.-W.; Privalsky, M.L. Transcriptional silencing is defined by isoform- and heterodimer-specific interactions between nuclear hormone receptors and corepressors. Mol. Cell. Biol. 1998, 18, 5724-5733. [CrossRef] [PubMed]

154. Hong, S.H.; David, G.; Wong, C.W.; Dejean, A.; Privalsky, M.L. SMRT corepressor interacts with PLZF and with the PML-retinoic acid receptor alpha (RARalpha) and PLZF-RARalpha oncoproteins associated with acute promyelocytic leukemia. Proc. Natl. Acad. Sci. USA 1997, 94, 9028-9033. [CrossRef]

155. Kwok, C.; Zeisig, B.B.; Dong, S.; So, C.W. Forced homo-oligomerization of RARalpha leads to transformation of primary hematopoietic cells. Cancer Cell 2006, 9, 95-108. [CrossRef]

156. Breitman, T.R.; Selonick, S.E.; Collins, S.J. Induction of differentiation of the human promyelocytic leukemia cell line(HL-60) by retinoic acid. Proc. Natl. Acad. Sci. USA 1980, 77, 2936. [CrossRef]

157. Robertson, K.; Emami, B.; Collins, S. Retinoic acid resistant HL60 cells harbour a point mutation in the RAR ligand binding domain that confers dominant negative activities. Blood 1992, 80, 1885-1892. [CrossRef]

158. Kastner, P.; Lawrence, H.J.; Waltzinger, C.; Ghyselinck, N.B.; Chambon, P.; Chan, S. Positive and negative regulation of granulopoiesis by endogenous RARalpha. Blood 2001, 97, 1314-1320. [CrossRef]

159. Du, C.; Redner, R.L.; Cooke, M.P.; Lavau, C. Overexpression of wild-type retinoic acid receptor alpha (RAR alpha) recapitulates retinoic acid-sensitive transformation of primary myeloid progenitors by acute promyelocytic leukemia RAR alpha-fusion genes. Blood 1999, 94, 793-802. [CrossRef]

160. McKeown, M.R.; Corces, M.R.; Eaton, M.L.; Fiore, C.; Lee, E.; Lopez, J.T.; Chen, M.W.; Smith, D.; Chan, S.M.; Koenig, J.L.; et al. Superenhancer Analysis Defines Novel Epigenomic Subtypes of Non-APL AML, Including an RARalpha Dependency Targetable by SY-1425, a Potent and Selective RARalpha Agonist. Cancer Discov. 2017, 7, 1136-1153. [CrossRef]

161. Schlenk, R.F.; Dohner, K.; Kneba, M.; Gotze, K.; Hartmann, F.; Del Valle, F.; Kirchen, H.; Koller, E.; Fischer, J.T.; Bullinger, L.; et al. Gene mutations and response to treatment with all-trans retinoic acid in elderly patients with acute myeloid leukemia. Results from the AMLSG Trial AML HD98B. Haematologica 2009, 94, 54-60. [CrossRef] [PubMed]

162. Schlenk, R.F.; Frohling, S.; Hartmann, F.; Fischer, J.T.; Glasmacher, A.; del Valle, F.; Grimminger, W.; Gotze, K.; Waterhouse, C.; Schoch, R.; et al. Phase III study of all-trans retinoic acid in previously untreated patients 61 years or older with acute myeloid leukemia. Leukemia 2004, 18, 1798-1803. [CrossRef] [PubMed]

163. Senapati, P.; Dey, S.; Sudarshan, D.; Das, S.; Kumar, M.; Kaypee, S.; Mohiyuddin, A.; Kodaganur, G.S.; Kundu, T.K. Oncogene c-fos and mutant R175H p53 regulate expression of Nucleophosmin implicating cancer manifestation. FEBS J. 2018, 285, 3503-3524. [CrossRef] [PubMed]

164. Tsimberidou, A.M.; Tirado-Gomez, M.; Andreeff, M.; O’Brien, S.; Kantarjian, H.; Keating, M.; Lopez-Berestein, G.; Estey, E. Single-agent liposomal all-trans retinoic acid can cure some patients with untreated acute promyelocytic leukemia: An update of The University of Texas MD Anderson Cancer Center Series. Leuk. Lymphoma 2006, 47, 1062-1068. [CrossRef]

165. Jakubiuk-Tomaszuk, A.; Murcia Pienkowski, V.; Zietkiewicz, S.; Rydzanicz, M.; Kosinska, J.; Stawinski, P.; Szuminski, M.; Ploski, R. Syndromic chorioretinal coloboma associated with heterozygous de novo RARA mutation affecting an amino acid critical for retinoic acid interaction. Clin. Genet. 2019, 96, 371-375. [CrossRef]

166. Tan, J.; Ong, C.K.; Lim, W.K.; Ng, C.C.; Thike, A.A.; Ng, L.M.; Rajasegaran, V.; Myint, S.S.; Nagarajan, S.; Thangaraju, S.; et al. Genomic landscapes of breast fibroepithelial tumors. Nat. Genet. 2015, 47, 1341-1345. [CrossRef]

167. El Hajj, H.; Dassouki, Z.; Berthier, C.; Raffoux, E.; Ades, L.; Legrand, O.; Hleihel, R.; Sahin, U.; Tawil, N.; Salameh, A.; et al. Retinoic acid and arsenic trioxide trigger degradation of mutated NPM1, resulting in apoptosis of AML cells. Blood 2015, 125, 3447-3454. [CrossRef] 
168. Martelli, M.P.; Gionfriddo, I.; Mezzasoma, F.; Milano, F.; Pierangeli, S.; Mulas, F.; Pacini, R.; Tabarrini, A.; Pettirossi, V.; Rossi, R.; et al. Arsenic trioxide and all-trans retinoic acid target NPM1 mutant oncoprotein levels and induce apoptosis in NPM1-mutated AML cells. Blood 2015, 125, 3455-3465. [CrossRef]

169. Mugoni, V.; Panella, R.; Cheloni, G.; Chen, M.; Pozdnyakova, O.; Stroopinsky, D.; Guarnerio, J.; Monteleone, E.; Lee, J.D.; Mendez, L.; et al. Vulnerabilities in mIDH2 AML confer sensitivity to APL-like targeted combination therapy. Cell Res. 2019, 29, 446-459. [CrossRef]

170. Boutzen, H.; Saland, E.; Larrue, C.; de Toni, F.; Gales, L.; Castelli, F.A.; Cathebas, M.; Zaghdoudi, S.; Stuani, L.; Kaoma, T.; et al. Isocitrate dehydrogenase 1 mutations prime the all-trans retinoic acid myeloid differentiation pathway in acute myeloid leukemia. J. Exp. Med. 2016, 213, 483-497. [CrossRef]

171. Kozono, S.; Lin, Y.M.; Seo, H.S.; Pinch, B.; Lian, X.; Qiu, C.; Herbert, M.K.; Chen, C.H.; Tan, L.; Gao, Z.J.; et al. Arsenic targets Pin1 and cooperates with retinoic acid to inhibit cancer-driving pathways and tumor-initiating cells. Nat. Commun. 2018, 9, 3069. [CrossRef] [PubMed]

172. Wei, S.; Kozono, S.; Kats, L.; Nechama, M.; Li, W.; Guarnerio, J.; Luo, M.; You, M.H.; Yao, Y.; Kondo, A.; et al. Active Pin1 is a key target of all-trans retinoic acid in acute promyelocytic leukemia and breast cancer. Nat. Med. 2015, 21, 457-466. [CrossRef] [PubMed]

173. Paubelle, E.; Zylbersztejn, F.; Maciel, T.T.; Carvalho, C.; Mupo, A.; Cheok, M.; Lieben, L.; Sujobert, P.; Decroocq, J.; Yokoyama, A.; et al. Vitamin D Receptor Controls Cell Stemness in Acute Myeloid Leukemia and in Normal Bone Marrow. Cell Rep. 2020, 30, 739-754. [CrossRef] [PubMed]

(C) 2020 by the authors. Licensee MDPI, Basel, Switzerland. This article is an open access article distributed under the terms and conditions of the Creative Commons Attribution (CC BY) license (http://creativecommons.org/licenses/by/4.0/). 